Pontifícia Universidade $C_{\text {atólica }}$

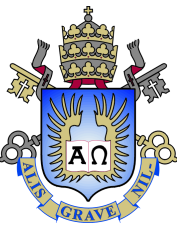

Gustavo Cicchelli de Sá Vieira

The political economy of fiscal multipliers

Dissertation presented to the Programa de Pós-graduação em Economia of PUC-Rio in partial fulfillment of the requirements for the degree of Mestre em Economia.

Advisor: Prof. Eduardo Zilberman 


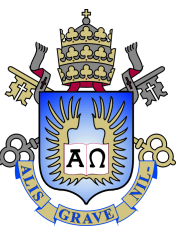

Gustavo Cicchelli de Sá Vieira

\section{The political economy of fiscal multipliers}

Dissertation presented to the Programa de Pós-graduação em Economia of PUC-Rio in partial fulfillment of the requirements for the degree of Mestre em Economia. Approved by the undersigned Examination Committee.

Prof. Eduardo Zilberman

Advisor

Departamento de Economia - PUC-Rio

Prof. Tiago Couto Berriel Departamento de Economia - PUC-Rio

Prof. Luciano Vereda Oliveira Universidade Federal Fluminense - UFF

Prof. Monica Herz

Coordenador Setorial do Centro de Ciências Sociais - PUC-Rio 
All rights reserved.

\section{Gustavo Cicchelli de Sá Vieira}

B.A., Economics, Universidade de Brasília (UnB), 2014.

Ficha Catalográfica

Cicchelli de Sá Vieira, Gustavo

The political economy of fiscal multipliers / Gustavo Cicchelli de Sá Vieira; orientador: Eduardo Zilberman. - 2017.

v., 53 f: il. color. ; $30 \mathrm{~cm}$

Dissertação (mestrado) - Pontifícia Universidade Católica do Rio de Janeiro, Departamento de Economia.

Inclui bibliografia

1. Economia - Teses. 2. Multiplicadores fiscais;. 3. Déficits fiscais;. 4. Política fiscal;. 5. Economia política.. I. Zilberman, Eduardo. II. Pontifícia Universidade Católica do Rio de Janeiro. Departamento de Economia. III. Título.

CDD: 330 


\section{Acknowledgments}

I would first like to thank my thesis advisor Dudu Zilberman for all the help and availability always. Whenever I had doubts, he steered me in the right the direction.

I would also like to thank my parents, my brother and my my sister for the unconditional love.

I thank all the friends I've made in PUC-Rio for all the knowledge and happiness shared here.

Finally, I express my profound gratitude to PUC-Rio, CAPES and Vinci Partners for the financial support, without which this work would not have been realized. 


\section{Abstract}

Cicchelli de Sá Vieira, Gustavo; Zilberman, Eduardo (Advisor). The political economy of fiscal multipliers. Rio de Janeiro, 2017. 53p. Dissertação de Mestrado - Departamento de Economia, Pontifícia Universidade Católica do Rio de Janeiro.

This paper investigates if fiscal fragility influences the magnitude of fiscal multipliers. We define states of fiscal fragility based on the literature on politico-institutional determinants of fiscal deficits. Using quarterly data for 44 countries, we find that fiscal multipliers in fiscally fragile economies are smaller than in economies expected to have greater surpluses.

\section{Keywords}

Fiscal multipliers; Fiscal deficits; Fiscal policy; Political economy. 


\section{Resumo}

Cicchelli de Sá Vieira, Gustavo; Zilberman, Eduardo. A economia política dos multiplicadores fiscais. Rio de Janeiro, 2017. 53p. Dissertação de Mestrado - Departamento de Economia, Pontifícia Universidade Católica do Rio de Janeiro.

Esse artigo investiga se a fragilidade fiscal influencia a magnitude dos multiplicadores fiscais. Nós definimos estados de fragilidade fiscal baseados na literatura de determinantes político-institucionais de déficits fiscais. Utilizando dados trimestrais para 44 países, encontramos evidências de que os multiplicadores fiscais de economias em situação fiscal frágil são menores do que os multiplicadores dos países com maior fluxo esperado de geração de superávits.

\section{Palavras-chave}

Multiplicadores fiscais; Déficits fiscais; Política fiscal; Economia política. 


\section{Table of contents}

1 Introduction $\quad 12$

2 Fiscal Fragility and politico-institutional determinants of deficits $\quad 15$

$\begin{array}{lll}2.1 & \text { Intertemporal Budget Constraint } & 15\end{array}$

$\begin{array}{ll}2.2 \text { Deficit Determinants } & 16\end{array}$

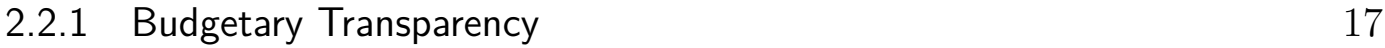

$\begin{array}{ll}\text { 2.2.2 Political Polarization } & 18\end{array}$

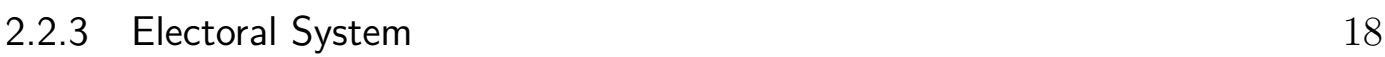

$\begin{array}{ll}\text { 2.2.4 Durability of Governments } & 19\end{array}$

3 Methodology 20

3.1 Panel Structural VAR - IMV 20

3.2 Interacted Panel VAR 22

$\begin{array}{lll}3.3 & \text { Fiscal Multipliers } & 22\end{array}$

4 Data $\quad 24$

5 Results $\quad 26$

5.1 Fiscal Responsibility Law 27

$\begin{array}{ll}5.2 \text { Political Polarization } & 29\end{array}$

5.3 Electoral System 31

5.4 Tenure Duration 33

5.5 Debt and State-Variables 35

5.5.1 Debt and Fiscal Responsibility Law 35

$\begin{array}{lll}6 & \text { Conclusion } & 39\end{array}$

A Data Appendix $\quad 42$

A.1 Political Polarization Index $\quad 42$

B Robustness Checks $\quad 43$

B.1 Debt and State Variables 43

B.2 High income countries $\quad 50$

B.3 Emerging countries $\quad 52$ 


\section{List of figures}

1.1 Cumulative Fiscal Multipliers in countries with High Debt (hdebt) an Low Debt (ldebt); Source: Ilzetzki et al, (2013)

5.1 Unconditional Cumulative multiplier Ratio of the cumulative increase in the net present value of GDP and the cumulative increase in the net present value of government consumption. Triggered by a shock to government consumption. Dotted lines represent $90 \%$ confidence interval based on Monte Carlo simulations 26

5.2 High income vs. Developing countries multipliers. Source: IMV 27

5.3 IMV Cumulative multiplier: Countries with/without Fiscal Responsibility Law. Ratio of the cumulative increase in the net present value of GDP and the cumulative increase in the net present value of government consumption. Triggered by a shock to government consumption.

5.4 IPVAR Cumulative multiplier: Countries with/without Fiscal Responsibility Law. Ratio of the cumulative increase in the net present value of GDP and the cumulative increase in the net present value of government consumption. Triggered by a shock to government consumption.

5.5 IMV Cumulative multiplier: Countries with/without Political Polarization. Ratio of the cumulative increase in the net present value of GDP and the cumulative increase in the net present value of government consumption. Triggered by a shock to government consumption.

5.6 IPVAR Cumulative multiplier: Countries with/without Political Polarization. Ratio of the cumulative increase in the net present value of GDP and the cumulative increase in the net present value of government consumption. Triggered by a shock to government consumption.

5.7 IMV Cumulative multiplier: Countries with/without Proportional Electoral System. Ratio of the cumulative increase in the net present value of GDP and the cumulative increase in the net present value of government consumption. Triggered by a shock to government consumption.

5.8 IPVAR Cumulative multiplier: Countries with/without Proportional Electoral System. Ratio of the cumulative increase in the net present value of GDP and the cumulative increase in the net present value of government consumption. Triggered by a shock to government consumption.

MV Cumulative multiplier: Countries with short/long Tenure Duration. Ratio of the cumulative increase in the net present value of GDP and the cumulative increase in the net present value of government consumption. Triggered by a shock to government consumption. 
5.10 IPVAR Cumulative multiplier: Countries with short/long Tenure Duration. Ratio of the cumulative increase in the net present value of GDP and the cumulative increase in the net present value of government consumption. Triggered by a shock to government consumption.

5.11 IPVAR Cumulative multiplier: High Debt Countries with and without fiscal responsibility law. Ratio of the cumulative increase in the net present value of GDP and the cumulative increase in the net present value of government consumption. Triggered by a shock to government consumption.

5.12 IPVAR Cumulative multiplier: Low Debt Countries with and without fiscal responsibility law. Ratio of the cumulative increase in the net present value of GDP and the cumulative increase in the net present value of government consumption. Triggered by a shock to government consumption.

5.13 IPVAR Cumulative multiplier: Countries equipped with Fiscal Responsibility laws with high/low debt. Ratio of the cumulative increase in the net present value of GDP and the cumulative increase in the net present value of government consumption. Triggered by a shock to government consumption.

5.14 IPVAR Cumulative multiplier: Countries without Fiscal Responsibility laws with high/low debt. Ratio of the cumulative increase in the net present value of GDP and the cumulative increase in the net present value of government consumption. Triggered by a shock to government consumption.

B.1 IPVAR Cumulative multiplier: High Debt Countries with and without political polarization.

B.2 IPVAR Cumulative multiplier: Low Debt Countries with and without political polarization.

B.3 IPVAR Cumulative multiplier: Countries without Political Polarization with high/low debt.

B.4 IPVAR Cumulative multiplier: Countries with Political Polarization with high/low debt.

B.5 High Debt Countries with and without proportional electoral system. 45

B.6 IPVAR Cumulative multiplier: Low Debt Countries with and without proportional electoral system..

B.7 IPVAR Cumulative multiplier: Countries without proportional electoral system with high/low debt.

B.8 IPVAR Cumulative multiplier: Countries with proportional electoral system with high/low debt.

B.9 IPVAR Cumulative multiplier: High Debt Countries with short/long tenures.

B.10 IPVAR Cumulative multiplier: Low Debt Countries short/long tenures. 48

B.11 IPVAR Cumulative multiplier: Countries with Long Tenures with high/low debt.

B.12 IPVAR Cumulative multiplier: Countries with Short Tenures with high/low debt. 
B.13 IPVAR Cumulative multiplier: High Income Countries with/without Fiscal Responsibility Law.

B.14 IPVAR Cumulative multiplier: High Income Countries with/without Political Polarization.

B.15 IPVAR Cumulative multiplier: High Income Countries with/without Proportional Electoral System.

B.16 IPVAR Cumulative multiplier: High Income Countries with long/short tenure.

B.17 IPVAR Cumulative multiplier: Emerging Countries with/without Fiscal Responsibility Law.

B.18 IPVAR Cumulative multiplier: Emerging Countries with/without Political Polarization.

B.19 IPVAR Cumulative multiplier: Emerging Countries with/without Proportional Electoral System.

B.20 IPVAR Cumulative multiplier: Emerging Countries with long/short tenure 


\section{List of tables}

1.1 Output Fiscal Multipliers' Estimates 12

4.1 Correlation Between Fiscal Fragility Indicators 25

4.2 Correlation Between Politico-Institutional State Variables 25 


\section{1 \\ Introduction}

The debate over fiscal policy's ability to stimulate aggregate activity has returned to the limelight due to the special conditions of hegemonic Economies during the great crisis of 2008. With nominal interest rates next to zero, governments' reactions via monetary policy tend, in theory, to loose effectiveness. In order to mitigate the turmoil caused by that episode, most countries opted for great expansions on public expenditure aiming to maintain and create jobs.

However, although governments have substantially increased their level of expenditure, there is still no consensus on the effectiveness of these policies on stimulating aggregate activity. In other words, there is great variability on the size of fiscal multipliers on theoretical and empirical literature - depending on different hypothesis adopted and methodologies used. The table below shows a small review of empirical results on table $1.1^{1}$ :

Estimate

Blanchard and Perotti (2002)

Galí, Lopez-Salido and Vallés (2007)

\begin{tabular}{c|c|c}
\multicolumn{3}{c}{ Estimate } \\
\hline On Impact & \multicolumn{1}{c}{4 quarters } & 8 quarters \\
\hline 0.9 & 0.55 & 0.65 \\
0.41 & 0.31 & 0.68 \\
0.7 & 1 & 1.2 \\
0.65 & 0.27 & -0.74 \\
0.3 & 0.5 & 0.9 \\
\hline
\end{tabular}

Perotti (2008)

Mountford and Uhlig (2008)

Ramey (2008)

Source: Hall (2008)

Table 1.1: Output Fiscal Multipliers' Estimates

The impact of public expenditure on Economies is recurrently theme of researches, and seminal articles like (2) and (3) are representatives of this literature's starting point. However, it is also known that the largest part of fiscal multipliers' literature is based on the implicit hypothesis that they are invariant over the state of the economy. The relation between the great variability in the magnitude of multipliers and the state of the economies began to be explored much more recently with (4) - where authors analyse a possible

\footnotetext{
${ }^{1}$ Based on tables in (1).
} 
duality in multipliers when considering regimes of expansion/retraction of the economy.

From this bottom line, economists started to analyse this possible statedependency in several regimes. (5) (IMV henceforth) study possible dualities in regimes like: fixed/flexible exchange rate; high-income/emerging countries; closed/open to commerce; and high/low debt. The last topic is the one we are specifically interested in here, and that is so because the level of indebtedness is used as a proxy to a higher default risk. Figure 1.1 exposes their results considering countries with different debt levels.

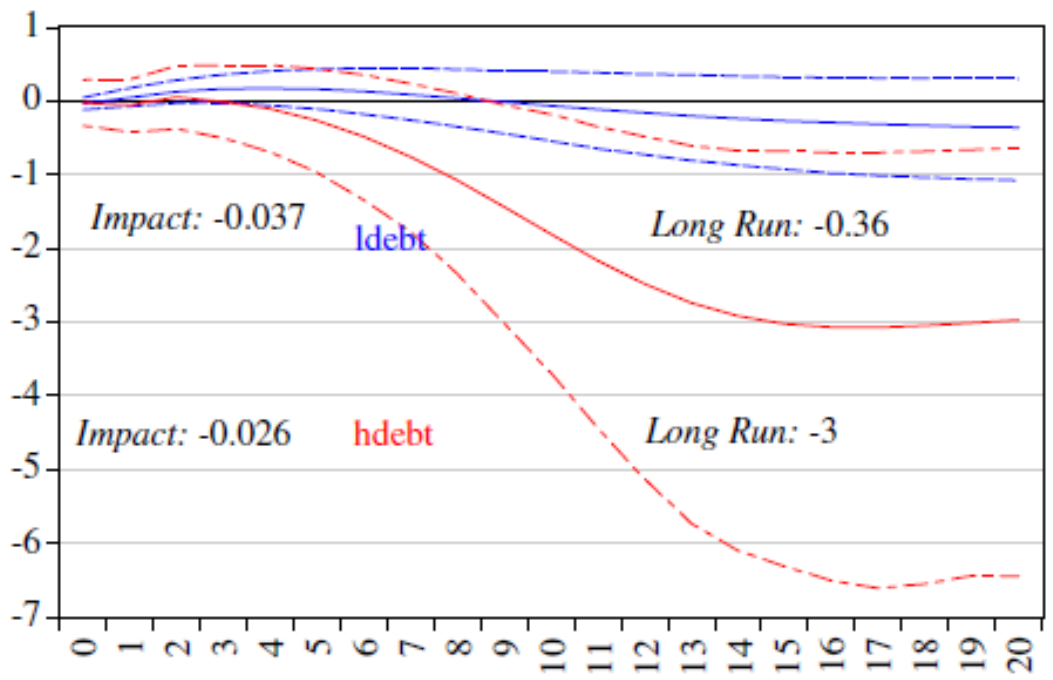

Figure 1.1: Cumulative Fiscal Multipliers in countries with High Debt (hdebt) an Low Debt (ldebt); Source: Ilzetzki et al, (2013)

Blue (Red) lines represent the product response over time when debt is low (high). (5) advocate that debt sustainability is an important factor in determining the output effect of government purchases, since magnitudes are extremelly state-dependent. They argument that the main channel through witch it occurs is: the anticipation of a nearly required fiscal tightening would offset the short-term expansionary effects of government expenditure, since agents would not invest or consume in the present in order to get ready for future contractionary policies. From now on, we will define Fiscal Fragility as a state associated to higher risks on honoring debt payments. This definition will be better explained in the next section.

Meanwhile, nothing guarantees that the debt level alone is a good indicator of fiscal fragility situations, since we are not considering the ability of countries on generating primary surpluses in the future. What we do here is to investigate how other measures of fiscal fragility affect the magnitude of fiscal multipliers, so that we can corroborate (or not) the exercise done by (5). 
To do this, it would be ideal to have data on expectations of future primary results. But since we are dealing with a 39 countries' unbalanced panel, these data are not easily available (if not unavailable). Our solution to that is to look on the literature on politico-institutional determinants of deficits and use this information to proxy fiscal fragility states.

Countries that have these deficits-enhancing characteristics will be considered into a fiscal fragility situation. Our contribution is to search for alternative definitions of fiscal fragility looking to proxies of fiscal balances' path. We also contribute building a new dataset merging the unbalanced panel built by (5) with a politico-institutional dataset that uses IMF and $\mathrm{IDB}^{2}$ as sources. We can anticipate here that our results indicate that countries equipped with fiscal responsibility laws have long run multipliers bigger than 2, while countries without these institutional devices have fiscal multipliers lower than zero ${ }^{3}$. Other politico-institutional arrangements provide similar results, although the difference between the magnitude of multipliers in good and bad fiscal states is smaller.

This work is divided as follows: beyond this introduction, chapter 2 has a theoretical motivation to the usage of different fiscal fragility indicators and a little summary on the literature on politico-institutional determinants of deficits. Chapter 3 presents the methodology used in this work. Chapter 4 describes the data. Chapter 5 describes the results obtained here. Finally, chapter 6 concludes.

${ }^{2}$ Respectively in (6) and (7).

${ }^{3}$ This results are obtained using the methodology present in (5), and are corroborated by the methodology present in (8). 


\section{2}

\section{Fiscal Fragility and politico-institutional determinants of deficits}

On this chapter we derive government's intertemporal budget constraint to demonstrate that both the debt size and fiscal balances are related, and are also important to determine a country's solvency level. After that, we show that politico-institutional characteristics proxy the ability of countries to react to negative fiscal shocks by improving their fiscal balances on the future. We try to link these two areas of the literature, and by doing that we give theoretical support to the usage of new fiscal fragility indexes.

\section{1}

\section{Intertemporal Budget Constraint}

The notion of fiscal fragility is associated with a higher risk of default. In order to motivate the usage of different fiscal fragility indicators, we will use the intertemporal government's budget constraint. To get there, we start showing a simplified period-by-period government budget constraint in a world with uncertainty:

$$
\operatorname{Debt}_{t}=\operatorname{Debt}_{t-1}\left(1+r_{t-1}\right)+\left(G_{t}-T_{t}\right)
$$

Where $\operatorname{Debt}_{t}$ is the real debt in period $\mathrm{t}, r_{t}$ is the real interest rate of the economy, $G_{t}$ is the primary government real expenditure and $T_{t}$ is the primary government real revenue. So, the expected debt stock in period t will be the stock of debt accumulated in the past added by it's respective interest payments and also the primary fiscal deficit in the period. One can isolate $D_{e b t_{t-1}}$ in equation 2-1 and iterate it forward. The result will be:

$$
\text { Debt }_{t-1}=E_{t-1}\left[\frac{\left(T_{t}-G_{t}\right)}{\left(1+r_{t-1}\right)}+\frac{\left(T_{t+1}-G_{t+1}\right)}{\left(1+r_{t-1}\right)\left(1+r_{t}\right)}+\ldots\right]
$$

Renaming variables:

$$
\text { Real Primary Result } \text { Pr }=\left(T_{t}-G_{t}\right)
$$

and also: 


$$
\text { Discount Rate } \text { R } t+j=\prod_{k=t}^{t+j}\left(1+r_{k}\right)
$$

We get to the following equation for the debt stock in period $t$ :

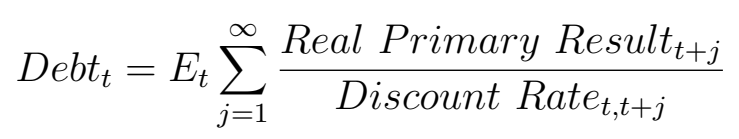

It is important to visualize this equation because almost all effort that has already been done in the literature to proxy fiscal fragility situations has been made by using debt indicators alone as state-variables. What we do here is to verify what happens to state-dependent fiscal multipliers if we use our proxies instead of the debt level. At some extent, it would be ideal to capture fiscal fragility states taking into account the debt size and the proxies for expected primary balances' path simultaneously, and we will also do that.

However, since we are dealing with a panel of 39 countries spanning a significant time horizon, those fiscal balances' projections are not available. We attack this problem by searching on literature on politico-institutional determinants of deficits. Moreover, these are relatively stable characteristics over time, whether a country has it or not today should be a good predictor of having it on the future.

Over the next section of this chapter we are going to review this specialized literature and bring arguments for why these politico-institutional factors are good deficit predictors in the medium run. More than that, we will show why these factors can bring information on the difficulty to react to an expansionary fiscal shock by increasing fiscal balances on the future.

\section{2}

\section{Deficit Determinants}

It is not our objective here to exhaust the literature on politico-institutional determinants of deficits. We are willing to show why political economy is a good source of information about deficits, and specifically show arguments in favor of our chosen politico-institutional state variables. There are already pretty good reviews of the political economy of fiscal deficits, notably (9) and (10). The last author starts asking why should fiscal deficits be run, and according to the work done by (11) in a seminal paper, deficits are meant to enhance consumption smoothing.

However, (9) brings relevant evidence that governments consistently obtain more deficits then they should if consumption smoothing really was their objective. Basically, there are three inductors to deficits' overrunning according to (10): preference heterogeneity between policymakers and voters; 
heterogeneity of fiscal preferences across politicians; heterogeneity of fiscal preferences across social groups or regions.

\subsection{1}

\section{Budgetary Transparency}

The effectiveness of numerical fiscal rules on the budgetary process is being questioned for a while on specialized literature. Since there are biases on deficits' decision process, imposing explicit numerical restrictions should be a way to pressure politicians in order to approximate their deficit choice to the socially optimal decision. ${ }^{1}$.

However, there is no consensus over the ability of numerical constraints on improving fiscal results ${ }^{2}$. (15) alerts for the dangers of creative accounting in case there is no transparency on the disclosure and elaboration of these traditional fiscal policy indicators. But when there are institutions that enhance transparency into the elaboration and execution of the budget, there is theoretical and empirical evidence that numerical fiscal rules are good indicators of better fiscal balances. (15) and (16), among others, support this thought that with more transparency there is less space for the government to run opportunistic deficits.

In order to obtain a good proxy to transparency on budgetary process, we are using an objective criteria: if a country has or not a Fiscal Responsibility Law. Eleven countries of our sample are equipped with a Fiscal Responsibility Laws - eight developing countries and three emerging: Argentina, Australia, Brazil, Chile, Colombia, Ecuador, Hungary, Mexico, Peru, Spain and United Kingdom. This kind of legal enforcement begins to appear in the mid 90's, but they get popular in the beginning of the 00's.

It is clear that several countries on our list are also famous for having defaulted on their debt a few times. Then, that could be a potential problem, since having or not Fiscal Responsibility Law would also indicate that the country in question used to have fiscal problems on the past. Although that is true, we try to account for that using country fixed effects in our estimation. We also do some robustness checks on the appendix

More about the nature of the data used to proxy transparency on the budgetary process can be found on chapter 4 .

\subsection{2}

${ }^{1}$ See more in $(9)$ and $(12)$.
${ }^{2}$ See for example $(13),(14)$. 


\section{Political Polarization}

The relation between political polarization and the occurrence of deficits is also well documented in the literature. (16) and (17) develop theoretical models that deal with the notion of Strategic Deficits. When there is a considerable ideological distance between the politician in power and a possible substitute, it is probable that they have distinct preferences in relation to sectors that will have more or less resources destined by the budget.

Then, there is a strong incentive to the incumbent to overspend in areas he judges more relevant, since there is a probability that he is going to be replaced by someone with different preferences. He is then anticipating future government expenditure running deficits, what will hamper the political adversary's capacity to spend public money on his own priority areas. Consequently, deficits are expected to be bigger if polarization is a characteristic of the political environment.

\subsection{3}

\section{Electoral System}

Each electoral system has some specificities in relation to the composition of congress. The proportional electoral system, for instance, is associated to the election of a greater number of political parties with relation to other electoral systems. In addition, one can consider that each political party represents an interest group. During budget's elaboration, each party will propose expenditures in areas that mostly benefit their respective interest groups. At the same time, tax revenues are supposed to be divided equally over all tax payers.

So, consider an environment with $\mathrm{N}$ political parties (interest groups). Since parties internalize only $1 / \mathrm{N}$ of the tax burden, but benefit fully from each dollar spent in a project meant to their respective interest group, there will be a bigger incentive to overspend in a congresses with more parties. The phenomena associated with more actors involved in the budgetary elaboration process is called fragmentation ${ }^{3}$.

However, as (10) claims: "Much of the empirical literature on the common pool problem treats deficits and spending as equivalent". This would require an additional hypothesis that taxation revenues are exogenous. And although there is a link between fragmentation and deficits, it is weaker than the link between fragmentation and spending. Further research is necessary to attack this problem.

\footnotetext{
${ }^{3}$ See also (9).
} 


\subsection{4}

\section{Durability of Governments}

Since governments are not eternal, it is plausible that there is a difference between it's discount rate and society's discount rate. (12) states that "a shortened expected tenure in office, the government would be more likely to engage in short-term policies at the expense of macroeconomic stability". Similarly, (18) say that "governments with short horizons act myopically and never quite tackle the hard choice".

Then, according to those authors, it becomes more probable that politicians with short expected tenure are more prone to run bigger deficits since they will not be in power when their attitudes become a significant problem. 


\section{3}

\section{Methodology}

On this chapter we describe the two methodologies we use to obtain fiscal multipliers' estimations, clarifying causality caveats. In addition, we show how we calculate fiscal multipliers.

\section{1}

\section{Panel Structural VAR - IMV}

We replicate the exercise done by (5), but in our case we are interested in the aforementioned politico-institutional state variables. We estimate our model and compare results in the same methodology basis with the original paper. Our structural model is:

$$
A Y_{i, t}=\sum_{k=1}^{K} C_{k} Y_{i, t-k}+B u_{i, t}
$$

The vector of endogenous variables is $Y_{i, t}$ is composed by: government's expenditure in consumption, GDP, current account over GDP ratio and the first difference of the real effective exchange rate. $C_{k}$ is the matrix of lagged coefficients, and each row contains the coefficients of one equation. Contemporaneous effects are into matrix A. The structural orthogonal shocks are represented by $u_{i, t}$, since $\mathrm{B}$ is a diagonal matrix. We also put some restrictions over the distribution of $u_{i, t}: E\left[u_{i, t}\right]=0$ and $E\left[u_{i, t} u_{i . t}^{\prime}\right]$ is the identity.

The reduced form is then:

$$
Y_{i, t}=\sum_{l=1}^{L} \tilde{C}_{k} Y_{i, t-l}+\tilde{B} u_{i, t}
$$

where $\tilde{C}=A^{-1} C$ and $\tilde{B}=A^{-1} B$.

First, we divide the sample into two groups based on each of the aforementioned state variables. Then, for each of these groups, we estimate $\tilde{C}$ in equation 3-2 by Panel OLS with fixed effects.

We use the Cholesky identification scheme ${ }^{1}$, which requires restrictions to contemporaneous effects of some endogenous variables. Here, we are assuming that the government expenditure does not react contemporaneously to any other endogenous variable. Which is pretty plausible since there are

${ }^{1}$ Of the type proposed by (19). 
legal and political procedures needed to modify the government's budget remember we are using data with quarterly frequency.

Although that is true, there are some legal features in modern budgets that can weaken our identification hypothesis: automatic stabilizers are legal devices that can condition the current level of government's expenditure to objective indicators. Even that these mechanisms are not always triggered, it is not unusual to have automatic stabilizers associated to the the business cycle of the economy.

However, even though the recursive identification method can become more inaccurate with automatic stabilizer playing a bigger role into budgets, we will argue here that data limitations and the lack of a variety of identification schemes entail that the Cholesky identification is still our best feasible option.

An alternative to that would be the utilization of the narrative approach used in (20), that consists in using military expenditure due to wars to capture exogenous fiscal shocks. (5) argue that this method has two main problems when dealing with a large panel of countries: first, the war was motivated only by global geopolitical factors and not domestic economic conditions; second, it is necessary that the only macroeconomic variable affected by the war must be the expenditure level. Both arguments were designed to deal with the US specific case.

That said, we order remaining macroeconomic variables as proposed by (5):

$$
Y_{i, t}=\left[\begin{array}{c}
g_{i, t} \\
y_{i, t} \\
c a_{i, t} \\
\operatorname{dreer}_{i, t}
\end{array}\right]
$$

The last two variables are open economies controls, and results are robust to their exclusion. In addition, (5) argument that estimates' results are highly sensitive to the lag selection. Since we are dealing with several divisions of the sample, it could be that differences in the results were due to the choice of how many lags are included in the model. So, we follow their proposal of using $L=4$ in all cases.

It is important to highlight here that our fiscal fragility state variables are correlated to an infinity of other characteristics that may represent other states of the economy. Consequently, we cannot say anything about causality when interpreting the results obtained using this methodology and the one to be presented next. Meanwhile, since there is a suggestive pattern in the results related to all of our fiscal fragility indicators, we can insinuate that 
fiscal fragility is impacting fiscal multipliers magnitudes.

\section{2}

\section{Interacted Panel VAR}

At this step, we use the Interacted Panel VAR methodology proposed by $(8)^{2}$. And even using the IPVAR approach, we still use the same vector of endogenous variables and also the fixed lag selection proposed by $(5)^{3}$. According to (8), the main innovation of this kind of model is the possibility to make estimates conditional on the state of the economy while using the whole sample. The structural model we are interested in is:

$$
\left[\begin{array}{cccc}
1 & 0 & 0 & 0 \\
\alpha_{i t, 0}^{21} & 1 & 0 & 0 \\
\alpha_{i t, 0}^{31} & \alpha_{i t, 0}^{32} & 1 & 0 \\
\alpha_{i t, 0}^{41} & \alpha_{i t, 0}^{42} & \alpha_{i t, 0}^{43} & 1
\end{array}\right]\left[\begin{array}{c}
g_{i, t} \\
y_{i, t} \\
c a_{i, t} \\
\text { reer }_{i, t}
\end{array}\right]=\sum_{l=1}^{L}\left[\begin{array}{cccc}
\alpha_{i t, l}^{11} & \alpha_{i t, l}^{12} & \alpha_{i t, l}^{13} & \alpha_{i t, l}^{14} \\
\alpha_{i t, l}^{21} & \alpha_{i t, l}^{22} & \alpha_{i t, l}^{23} & \alpha_{i t, l}^{24} \\
\alpha_{i t, l}^{31} & \alpha_{i t, l}^{32} & \alpha_{i t, l}^{33} & \alpha_{i t, l}^{34} \\
\alpha_{i t, l}^{41} & \alpha_{i t, l}^{42} & \alpha_{i t, l}^{43} & \alpha_{i t, l}^{44}
\end{array}\right]\left[\begin{array}{c}
g_{i, t-l} \\
y_{i, t-l} \\
c a_{i, t-l} \\
d r e e r_{i, t-l}
\end{array}\right]+U_{i, t}
$$

Where i represents a country and t represents a period in time. All $\alpha_{i t, l}^{j k}$ coefficients are time-varying, and follow the law of movement expressed below:

$$
\alpha_{i t, l}^{j k}=\beta_{i t, l}^{j k}+\gamma_{i t, l}^{j k} F_{i t}
$$

Note that if $F_{i t}=0$ in the whole sample, this model reduces to the Panel SVAR methodology.

Where $F_{i t}$ is the variable that represents a country's fiscal position at a certain time horizon. $F_{i t}$ can be a dummy or a continuous variable. $\beta_{i t, l}^{j k}$ is the coefficient associated with the respective endogenous variable alone, while $\gamma_{i t, l}^{j k}$ is the coefficient associated with the interaction between the fiscal position and the endogenous variable.

We estimate the structural model, and then obtain reduced form matrices for all values of the interaction terms we are interested in.

\section{3}

\section{Fiscal Multipliers}

Fiscal Multipliers are measures of how a one unity increase in a fiscal variable modifies the aggregate production of an Economy. We are interested here in two specific measures of multipliers: a) Impact multipliers; b) Cumulative multipliers. Cumulative multipliers are generalization of impact multipliers for all time horizons. Since there may exist significant delays on

${ }^{2}$ Also present in $(21)$.

${ }^{3}(8)$ also follow this same procedure. 
the effect of fiscal stimulus, our main measure of multipliers will be the Cumulative multiplier. These are calculated as follows:

$$
\begin{gathered}
\text { impact multiplier }=\frac{\Delta y_{0}}{\Delta g_{0}} \\
\text { cumul. multiplier }=\frac{\sum_{t=0}^{T} \Delta y_{t} /(1+i)^{t}}{\sum_{t=0}^{T} \Delta g_{t} /(1+i)^{t}}
\end{gathered}
$$

$\Delta y_{t}$ and $\Delta g_{t}$ correspond to the first difference of aggregate production and the first difference of government's consumption in period t, respectively. We obtain these variations using state-specific Impulse response functions due to a $1 \%$ standard deviation shock in government consumption. The interest rate used here is the median of the rates practiced in the selected sample. 


\section{4 \\ Data}

We construct a new dataset using 3 main sources: (5), IMF and IBD ${ }^{1}$. The result is a 39 countries' unbalanced panel with quarterly data spanning from 1975-2009. The major contribution of (5) was to collect actual quarterly data on government expenditure for all of these countries. They highlight the importance of using actual quarterly data to satisfy the hypothesis necessary to the identification scheme present in (19).

Again, our endogenous variables are: real government's consumption; country's GDP; ratio of the current account to GDP; and the first difference of the real effective exchange rate. They were all taken from (5), and were de-seasonalized with SEATS algorithm. These authors also treated for nonstationarity issues obtaining deviations from the quadratic trend when in case.

State Variables are divided in two sections: budgetary institutions and political variables. Budgetary institutions were taken from Fiscal Rules Dataset (IMF - (6)). The series we are using from this source is a dummy for a country having or not a Fiscal Responsibility Law. According to the definition in (6): Fiscal Responsibility Laws "typically set out procedural and transparency requirements, and in some cases also numerical rules". Or even: laws that elaborate on the government's collective responsibility to parliament for macrofiscal management ${ }^{2}$.

Political variables were taken from Dataset of Political Institution (IDB (7)). We use 3 measures built using this data source: a) a dummy for a country having or not Proportional Electoral System; b) a dummy for chief executive's tenure's duration being longer than the median in the whole sample; c) a dummy for a country having or not a polarized political system in a competitive electoral environment.

The second and third political variables need a little more explanation on their meaning. As we have seen on previous sections, governments with longer tenures tend to deliver lower deficits. Consider for example that a chief executive was in charge from 2000Q1-2003Q4. For all observations of the respective country during this period, we will consider the following as

\footnotetext{
${ }^{1}$ Respectively in (6) and (7).
}

${ }^{2}$ in $(22)$. 
the state variable: if the de facto duration of his tenure, 8 quarters, is bigger (lower) than the median duration of tenures over the panel, the observations will be considered as a long (short) tenure.

In addition, our definition of a polarized system is based on the following conditions: a) Elections are competitive; b) Chief executive's party doesn't have absolute majority in congress; c) Chief executive's party doesn't control all houses in congress; d) There is a relevant ideological distance between chief executive's party and the main coalition parties or the biggest opposition party $^{3}$.

In addition, we also expose in table 4.1 the correlation between our fiscal fragility indicators and traditional indebtedness' levels indicators in order to demonstrate that our state-variables are not using the same information previous studies have already used:

\begin{tabular}{cc|c} 
& Debt Level & IMV Indicator \\
\hline NPR & -0.173 & -0.207 \\
NPOL & -0.003 & -0.034 \\
FRL & -0.040 & -0.070 \\
LON & 0.027 & -0.061
\end{tabular}

Table 4.1: Correlation Between Fiscal Fragility Indicators

It is also important to show we are not being redundant in our state variables choice. Than, we also show the correlation between our politicoinstitutional variables in table 4.2 :

\begin{tabular}{cc|c|c|c} 
& NPR & NPOL & FRL & LON \\
\hline NPR & 1.000 & 0.382 & -0.018 & 0.178 \\
NPOL & 0.382 & 1.000 & -0.003 & 0.172 \\
FRL & -0.018 & -0.003 & 1.000 & 0.109 \\
LON & 0.178 & 0.172 & 0.109 & 1.000
\end{tabular}

Table 4.2: Correlation Between Politico-Institutional State Variables

${ }^{3}$ This is better explained on the Data Appendix. 


\section{Results}

This chapter shows the results obtained using both methodologies detailed above. But before we present them, we report the fiscal multiplier obtained without conditioning the estimation on any state variable. (8) highlight the importance of this previous result in order to establish a benchmark. Even though we are using two methodologies, the unconditional multiplier using the IPVAR is analogous to the one obtained using the Panel SVAR, since having null interaction terms to all observations reduces the IPVAR to the whole sample Panel SVAR ${ }^{1}$.

\section{Full Sample}

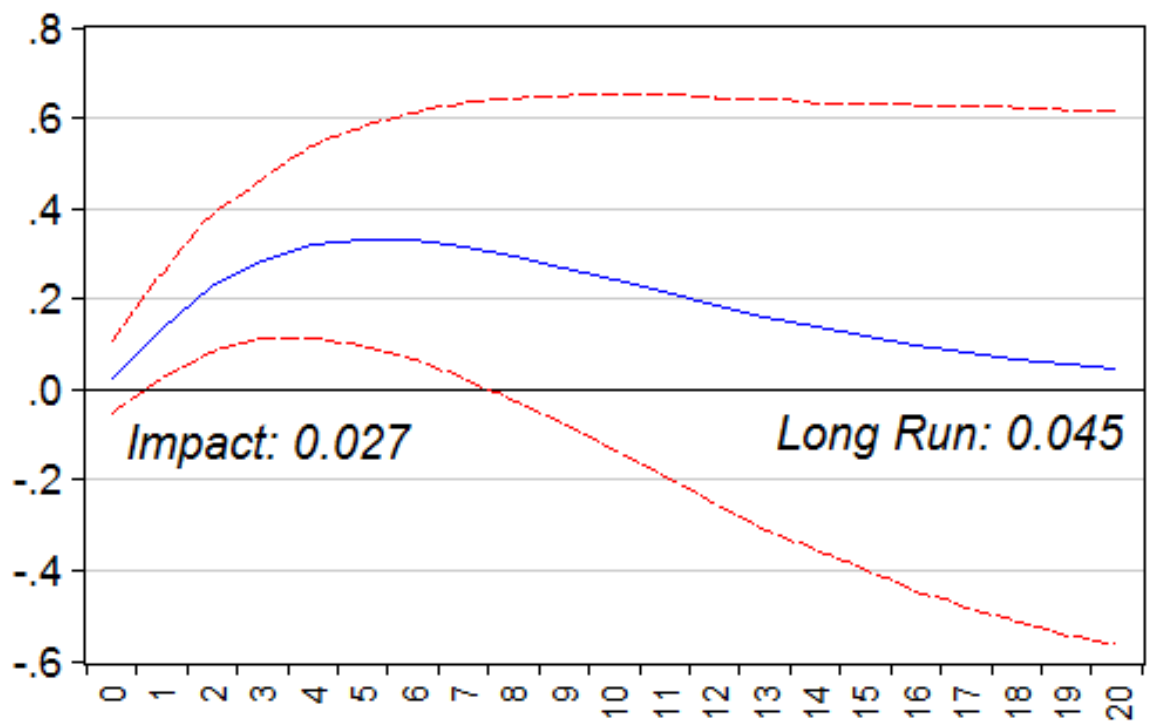

Figure 5.1: Unconditional Cumulative multiplier Ratio of the cumulative increase in the net present value of GDP and the cumulative increase in the net present value of government consumption. Triggered by a shock to government consumption. Dotted lines represent 90\% confidence interval based on Monte Carlo simulations

One can note from figure 5.1 that the unconditional fiscal multiplier is positive in all horizons, although its not statistically significant from zero in

${ }^{1}$ This can be easily seen looking to the law of motion's component in equation 3-3. 
most cases. This would suggest that fiscal policy is not effective in stimulating the economy. Even though we are using a data set that differs a little from the one used in (8), conclusions are alike.

We also present high income versus developing countries multipliers calculated by (5). Note that high-income countries have bigger multipliers in magnitude. This can be relevant when accessing our results, to show that the difference in our fiscal multipliers estimates is not only due to this specific grouping characteristic. Before we provide our estimates, we are going to show how many high-income countries and also how many developing countries there are in each subsample.
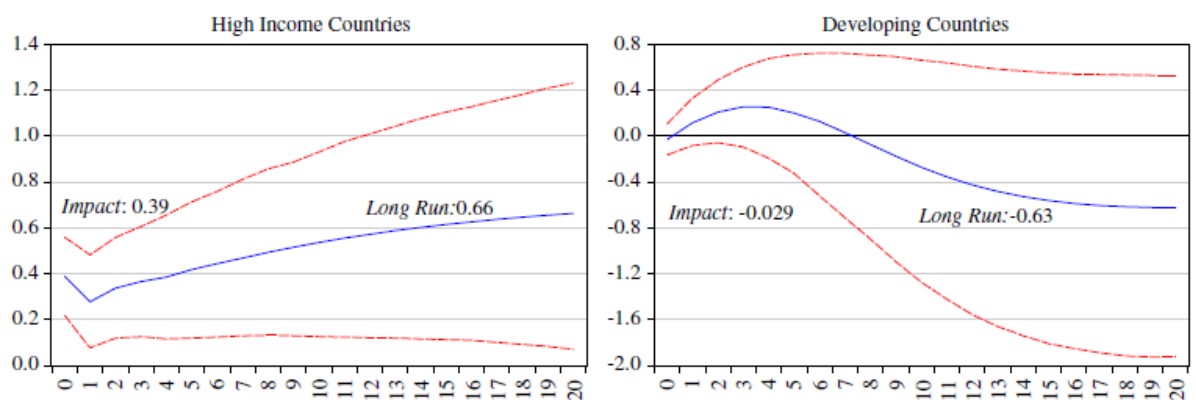

Figure 5.2: High income vs. Developing countries multipliers. Source: IMV

What we will do next is to compare the magnitude of fiscal multipliers when conditioned on our state-variables. Based on previously obtained results, it is expected that multipliers are lower in fiscal fragility situations. In each section, we are analysing a different state-variable, and we will present the results using the methodology proposed by (5) (henceforth called IMV methodology), followed by results obtained using the IPVAR methodology.

When using the IMV methodology, we will present two graphs: the left one represents the solid fiscal position, while the one in the right represents the bad fiscal position. In addition, when in the IPVAR Methodology, we are presenting a single graph: red lines represent fiscal fragility states, while the blue lines represent a better fiscal position. Dashed lines are $90 \%$ confidence intervals estimates for both methodologies.

We have also made robustness checks taking each country at a time out of the sample and estimating multipliers only for emerging/high-income countries. These are available on the appendix.

\section{1}

\section{Fiscal Responsibility Law}

Here we divided the sample into: (a) countries that have Fiscal Responsibility Laws and (b) countries that do not have Fiscal Responsibility 
Law. This classification is related to the transparency over the budgetary process, and countries that have this type of institutional resource are expected to obtain better primary results in the future. It is important to highlight that when a country begins to use Fiscal Responsibility Laws, it is very difficult for the same country to go back and withdraw this kind of enforcement. This characteristic is essentially good for us because it will be a better proxy for long term predictions of primary balances.

Considering countries that are equipped with fiscal responsibility laws, there are 132 observations related to developing countries and 107 related to high-income countries. On the other hand, considering countries that are not equipped with fiscal responsibility laws, there are 553 observations related to developing countries and 892 related to high income countries. These numbers are relative to the samples obtained using the IMV methodology.

From the impulse response functions, we construct the corresponding fiscal multipliers and expose them in figure 5.3. First we highlight that multipliers from both groups are statistically different from each other at all horizons. We can see that the impact multiplier for countries with Fiscal Responsibility Laws is 1.4 (statistically significant from zero at the $95 \%$ level) while countries that do not have this institutional device have impact multiplier equal to -0.12 (not statistically significant from zero). This suggests that budget's transparency is a critical determinant of multipliers' size.
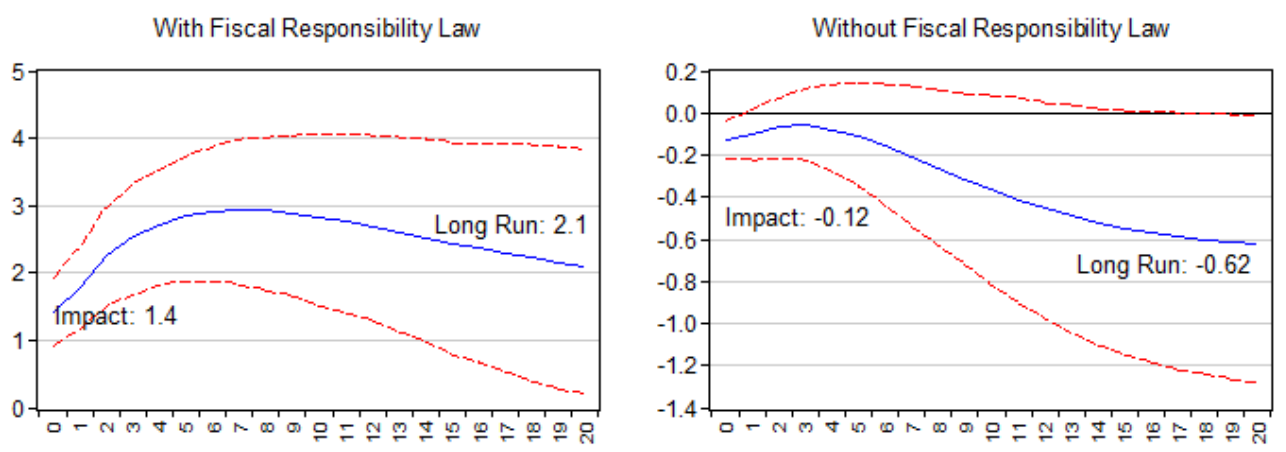

Figure 5.3: IMV Cumulative multiplier: Countries with/without Fiscal Responsibility Law. Ratio of the cumulative increase in the net present value of GDP and the cumulative increase in the net present value of government consumption. Triggered by a shock to government consumption.

The difference, however, is much more relevant in the long run: countries with Fiscal Responsibility Laws have long run multipliers equal to 2.1 which is much bigger in magnitude than the -0.62 long run multiplier for the other group. These evidences are in accordance with previous empirical and 
theoretical results ${ }^{2}$.

Results are corroborated when using the IPVAR methodology, although the difference is less relevant. In magnitude, long run multipliers are bigger than zero in countries with Fiscal Responsibility Laws, while countries that do not are equipped with this kind of budget's institution have negative fiscal multipliers in the long run.

With FRL vs. Without FRL

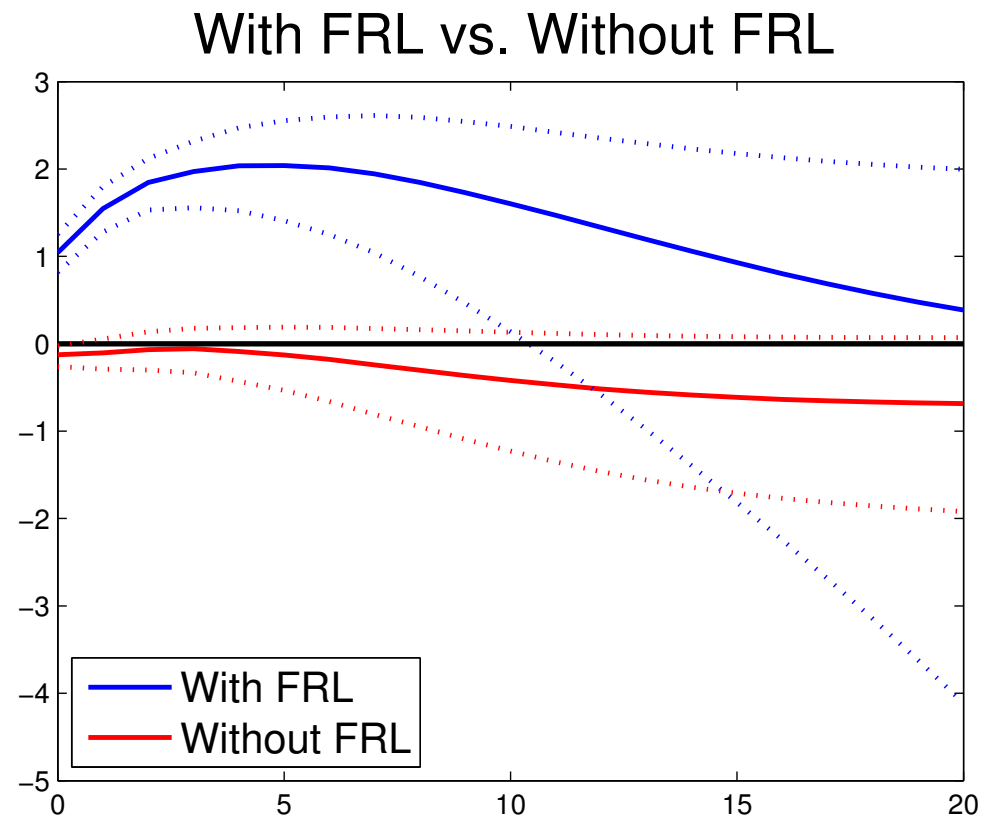

Figure 5.4: IPVAR Cumulative multiplier: Countries with/without Fiscal Responsibility Law. Ratio of the cumulative increase in the net present value of GDP and the cumulative increase in the net present value of government consumption. Triggered by a shock to government consumption.

\section{2}

\section{Political Polarization}

Next, we divide our sample into politically polarized/not politically polarized countries. Again, this measure takes into account the ideological distance between important political leaders. Strategical deficits literature would predict that polarized countries will have more deficits than the others. It's important to say that this state variable is more volatile than the previous one, so it will be a better proxy for the medium-term predictions of primary results.

Considering countries that are not politically polarized, there are 255 observations related to developing countries and 290 related to high-income

${ }^{2}$ Essentially, results taking into account multipliers in countries with high/low debt in (5), in (8), and also in the theoretical model proposed by (23). 
countries. On the other hand, considering countries that are politically polarized, there are 347 observations related to developing countries and 664 related to high income countries. These numbers are relative to the samples obtained using the IMV methodology.
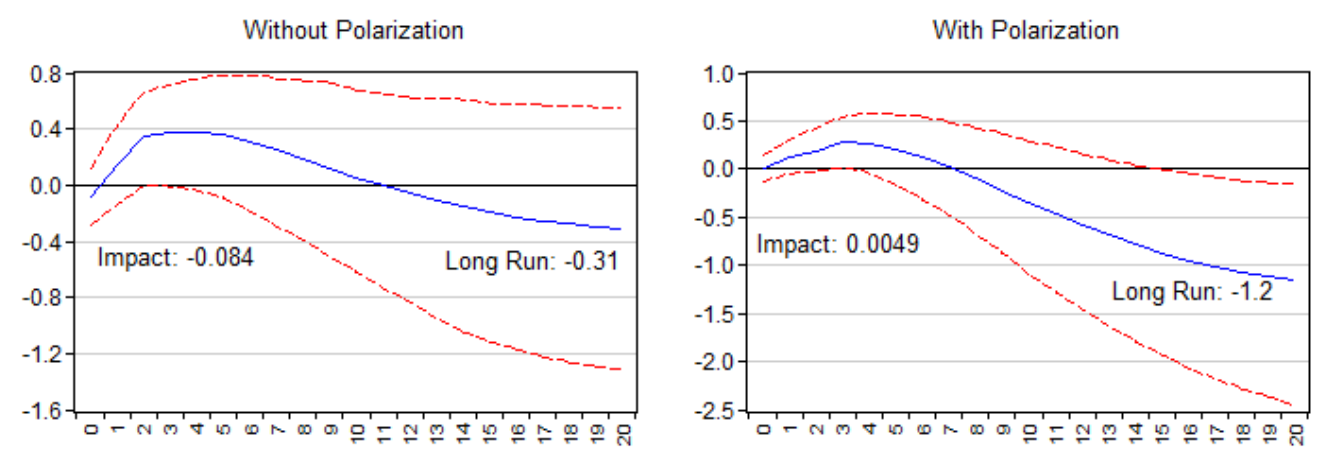

Figure 5.5: IMV Cumulative multiplier: Countries with/without Political Polarization. Ratio of the cumulative increase in the net present value of GDP and the cumulative increase in the net present value of government consumption. Triggered by a shock to government consumption.

Results for the subsample that accounts for non-polarized countries indicates that fiscal multipliers are not statistically different from zero at any horizon. The polarized subsample has similar results, but getting closer to the $20^{\text {th }}$ quarter, multipliers are statistically negative. Although this indicates that countries with more difficulty to obtain primary surpluses have lower multipliers, we cannot say that long-run multipliers are statistically different from each other since there is an overlapping of confidence intervals. However, magnitudes of multipliers are considerably lower in the polarized subsample.

When using the IPVAR methodology, estimates also shows similar evidence when comparing to the the IMV methodology. Non polarized countries' multipliers also have long run multipliers near to zero in magnitude, while polarized countries' also have multipliers approximately equal to -1 . 
Polarized vs. Non Polarized

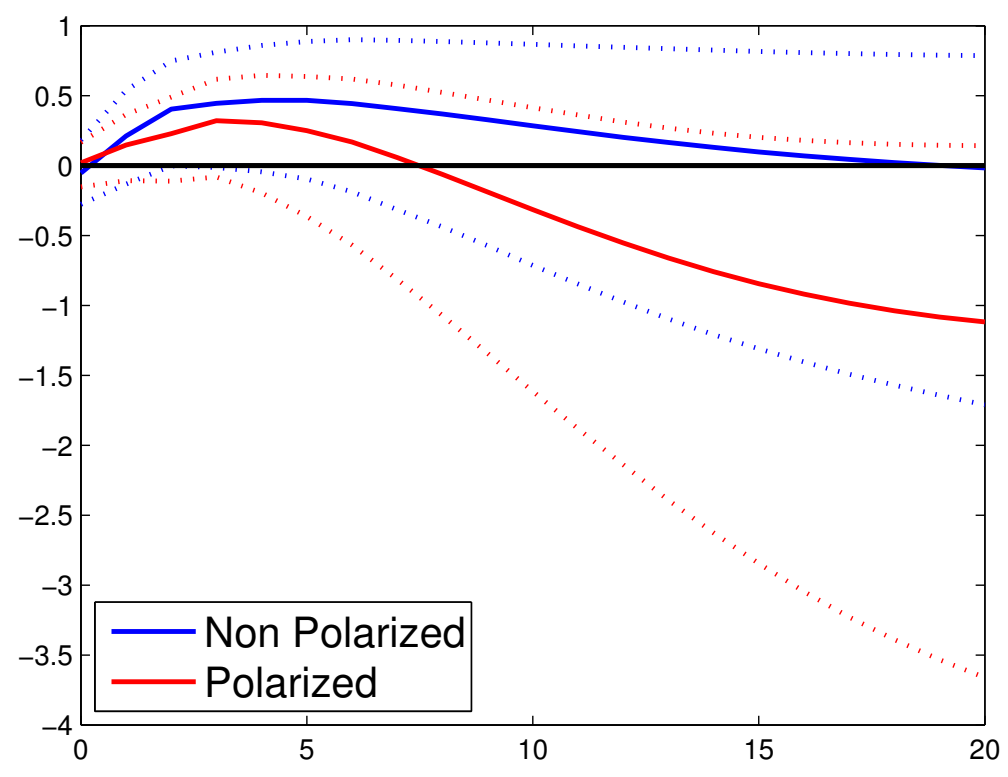

Figure 5.6: IPVAR Cumulative multiplier: Countries with/without Political Polarization. Ratio of the cumulative increase in the net present value of GDP and the cumulative increase in the net present value of government consumption. Triggered by a shock to government consumption.

\section{3}

\section{Electoral System}

At this stage we are going to separate samples based on the electoral system. We are dividing countries into ones that have a Proportional Electoral System or not. Countries that adopt this specific electoral system tend to elect more political parties then when they have alternative electoral systems. Fragmentation is a phenomena linked to the occurrence of deficits. And in this case, we are also dealing with a characteristic that is completely stable over time in countries.

Considering countries that do not adopt a proportional electoral system, there are 148 observations related to developing countries and 500 related to high-income countries. On the other hand, considering countries that adopt a proportional electoral system, there are 774 observations related to developing countries and 691 related to high income countries. These numbers are relative to the samples obtained using the IMV methodology.

Here the impact multiplier is lower in magnitude when countries do not have proportional electoral system. Although this is true, (5) defend that impact multipliers are less important in this kind of analysis since fiscal stimulus packages can only be implemented over time and there may be lags in the economy's response. 

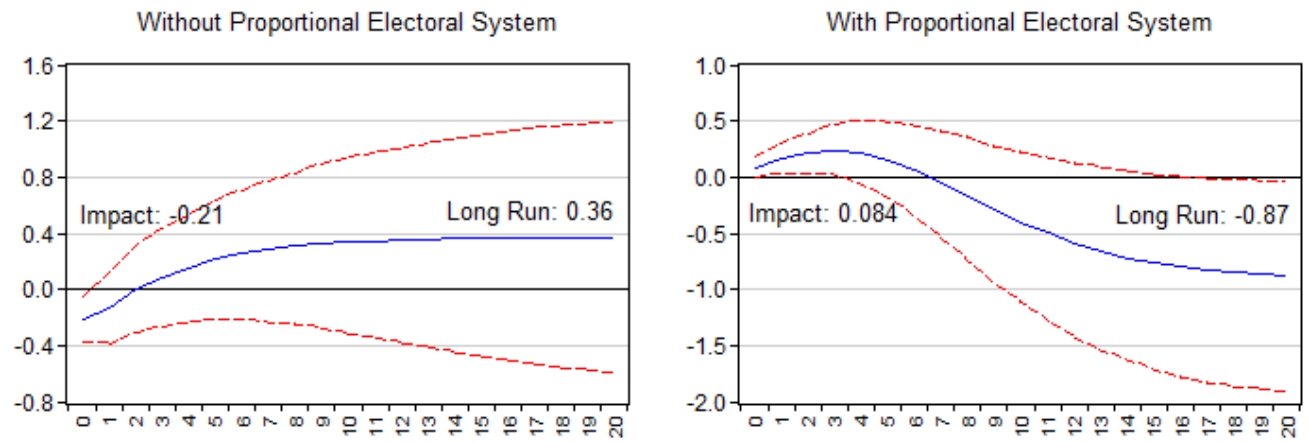

Figure 5.7: IMV Cumulative multiplier: Countries with/without Proportional Electoral System. Ratio of the cumulative increase in the net present value of GDP and the cumulative increase in the net present value of government consumption. Triggered by a shock to government consumption.

Long run multipliers for countries with proportional electoral systems are 0.36 , statistically equal to zero. On the other hand, when countries have proportional electoral system the analogous multiplier is -0.87 , statistically negative. But again, there is overlap in confidence intervals, what weakens the evidence obtained. IPVAR methodology also delivers pretty similar results. 


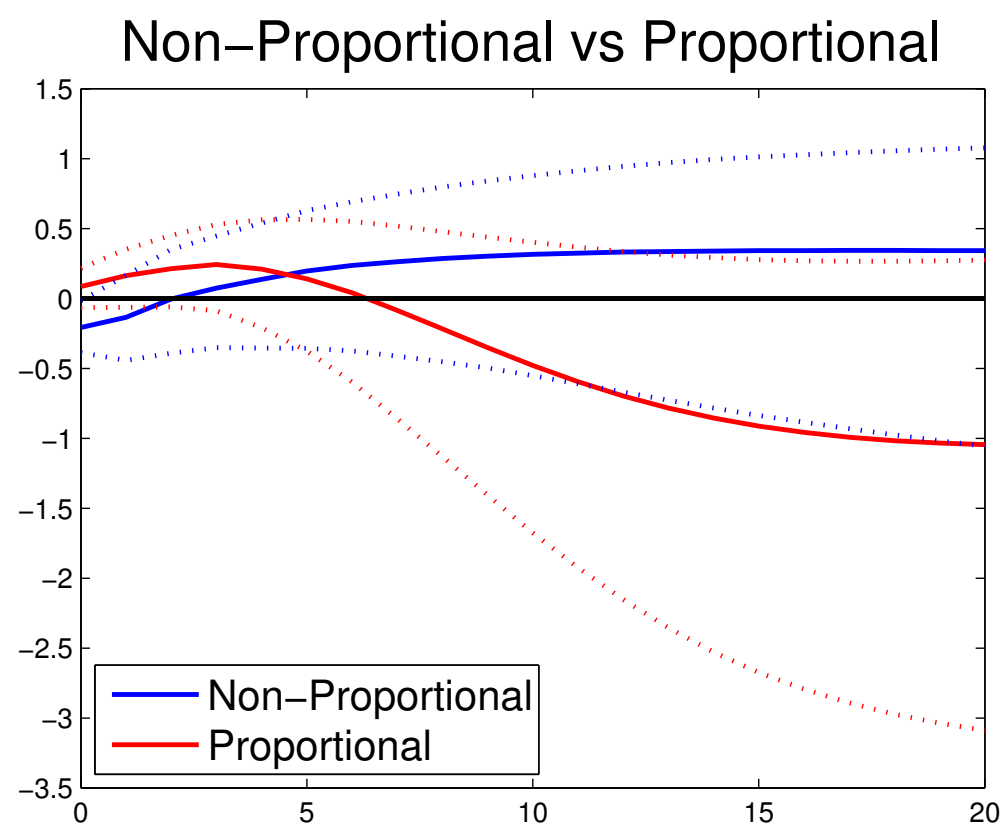

Figure 5.8: IPVAR Cumulative multiplier: Countries with/without Proportional Electoral System. Ratio of the cumulative increase in the net present value of GDP and the cumulative increase in the net present value of government consumption. Triggered by a shock to government consumption.

\section{4}

\section{Tenure Duration}

The cut used in this section is related to chief executive's tenure duration. It is well documented that governors with shorter tenure's duration are biased to focus on short-term policies, what induces more deficits. Then, longer tenure's are associated with stronger fiscal positions.

Considering countries that have long tenures, there are 246 observations related to developing countries and 734 related to high-income countries. On the other hand, considering countries that short tenures, there are 674 observations related to developing countries and 431 related to high income countries. These numbers are relative to the samples obtained using the IMV methodology.

Long run multipliers are bigger in magnitude in countries with longer tenure's duration. Here, confidence intervals overlap during all quarters analysed. Another relevant point is the dynamics of both multipliers. In the stronger fiscal position case, multipliers do not decrease in magnitude, and are 0.17 (statistically equal to zero). While fiscally fragile countries have long run multipliers near to -1 (but also statistically equal to zero). IPVAR methodology also corroborate the evidence obtained above. 

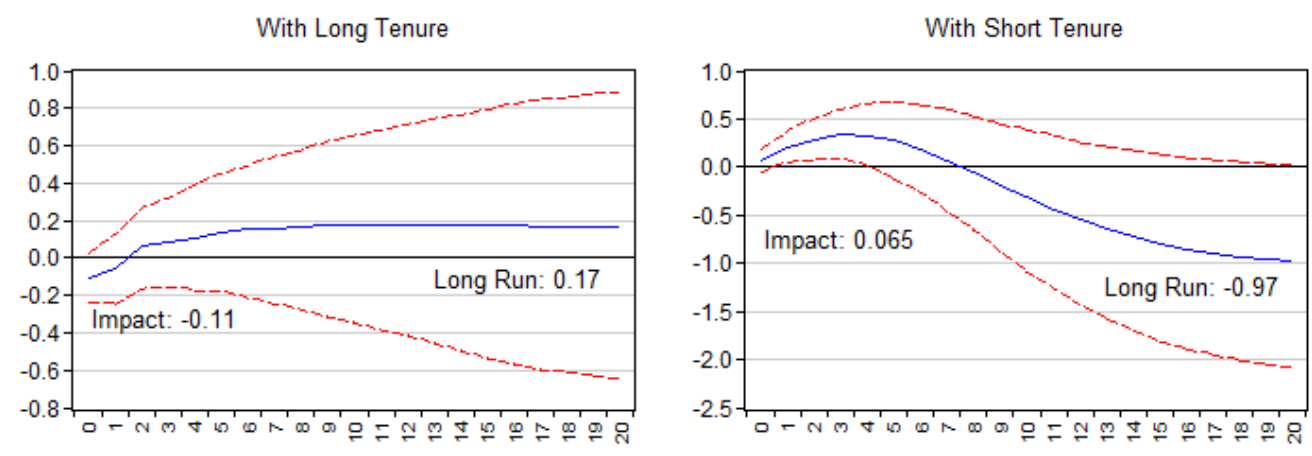

Figure 5.9: IMV Cumulative multiplier: Countries with short/long Tenure Duration. Ratio of the cumulative increase in the net present value of GDP and the cumulative increase in the net present value of government consumption. Triggered by a shock to government consumption.

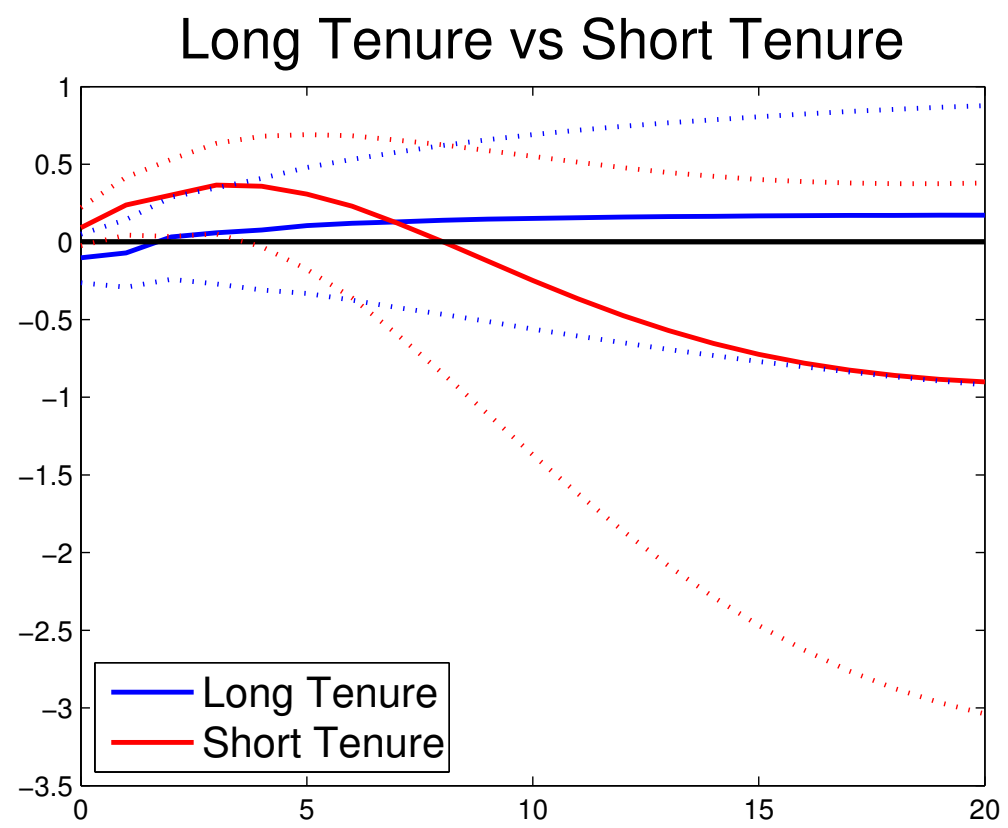

Figure 5.10: IPVAR Cumulative multiplier: Countries with short/long Tenure Duration. Ratio of the cumulative increase in the net present value of GDP and the cumulative increase in the net present value of government consumption. Triggered by a shock to government consumption. 


\section{5 \\ Debt and State-Variables}

On this section, we are using information on both debt size and fiscal balances' proxies to evaluate fiscal fragility states. On the following subsection we are going to show four comparisons. First, we compare countries with same level of indebtedness, and different abilities of fiscal balances' generation: a) High Debt with good fiscal balances vs. High Debt with bad fiscal balances; b) Low Debt with good fiscal balances vs . Low Debt with bad fiscal balances. In a second step, we compare countries with same ability of fiscal balances' generation, and different indebtedness levels: c) High Debt with good fiscal balances vs. Low Debt with good fiscal balances; d) High Debt with bad fiscal balances vs. Low Debt with bad fiscal balances.

We are going to present only results associated to the Fiscal Responsibility Law state-variable, since the same phenomena occurs in all four state-variables. Results for other state-variabes are shown in the Appendix. When we say high debt here, we are considering the observation on the 85th percentile of the level of indebtedness sample - that represents approximately to a $75 \%$ debt to GDP ratio. Symmetrically, we are considering the 15th percentile as a low level of indebtedness - that represents approximately to a $20 \%$ debt to GDP ratio ${ }^{3}$.

\subsection{1}

\section{Debt and Fiscal Responsibility Law}

From now on in the figures' legends, HD means High Debt, LD means Low Debt, FRL means countries equipped with fiscal responsibility laws and WFRL means countries without fiscal responsibility laws.

On figure 5.11 we compare multipliers of highly indebted countries. Those countries that are equipped with fiscal responsibility laws have bigger multipliers than those that do not have these institutional devices. When we are looking only to countries that have low levels of indebtedness, the same thing happens.

On next step, as exposed in figure 5.13, we are analysing only countries equipped with fiscal responsibility laws. In this case, the deterioration of fiscal multipliers caused by higher level of indebtedness does not occur, as it would be expected taking into consideration results in (5) and (8). It could be that a better expected performance in obtaining good primary results diminishes the default risk associated with higher debt levels.

\footnotetext{
${ }^{3}$ We also realize the same exercise considering percentiles 70 vs. 30 and 60 vs. 40 for robustness' checks, and results corroborate the ones we present here.
} 


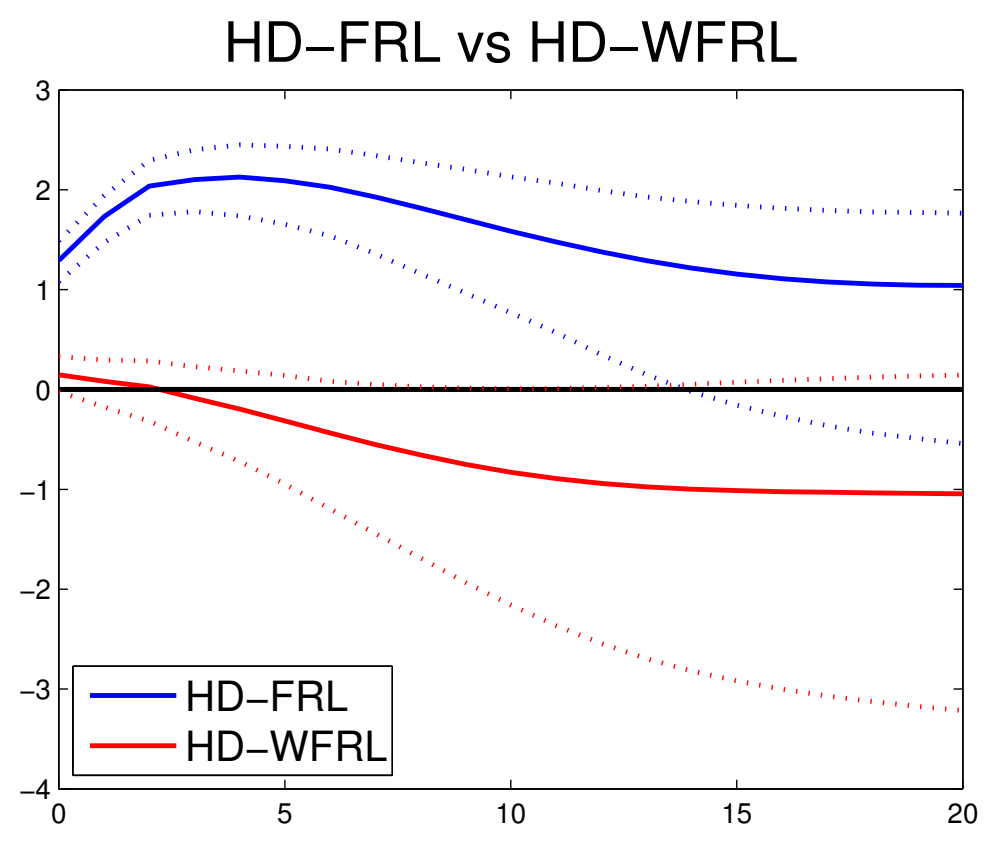

Figure 5.11: IPVAR Cumulative multiplier: High Debt Countries with and without fiscal responsibility law. Ratio of the cumulative increase in the net present value of GDP and the cumulative increase in the net present value of government consumption. Triggered by a shock to government consumption.

In figure 5.14 we evaluate only countries that do not have fiscal responsibility laws. Fiscal multipliers are statistically equal comparing high/low debt, although multipliers are again bigger, in magnitude, in countries with lower debt levels. 


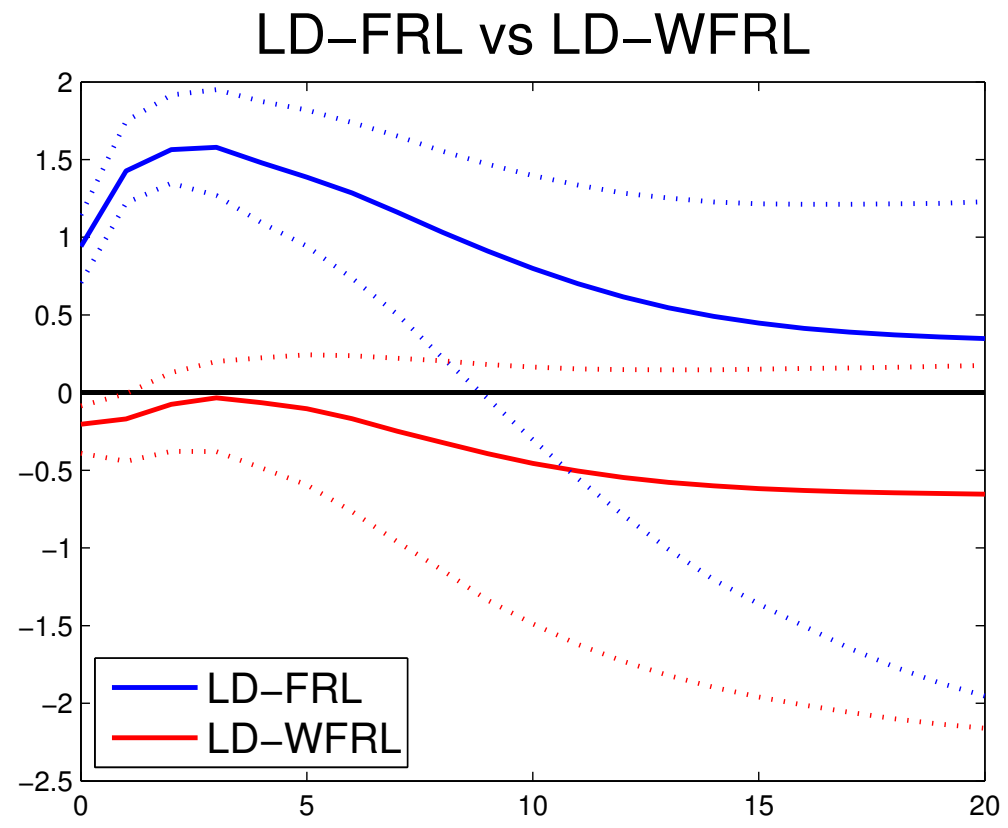

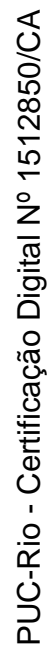

Figure 5.12: IPVAR Cumulative multiplier: Low Debt Countries with and without fiscal responsibility law. Ratio of the cumulative increase in the net present value of GDP and the cumulative increase in the net present value of government consumption. Triggered by a shock to government consumption.

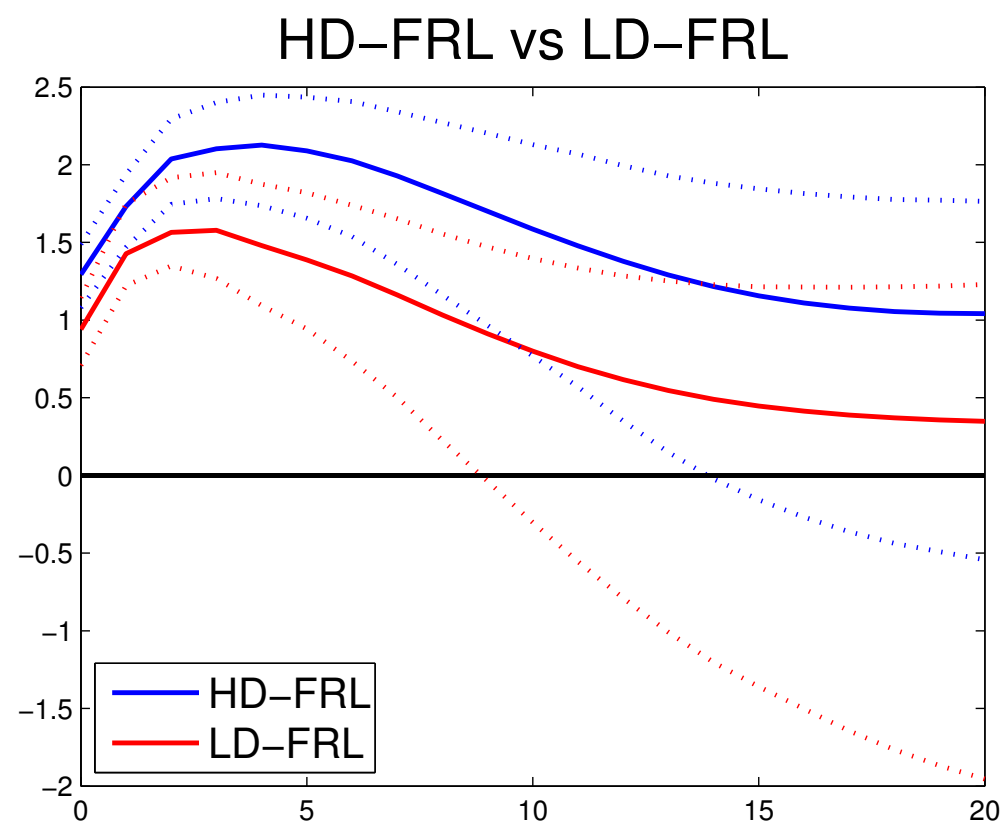

Figure 5.13: IPVAR Cumulative multiplier: Countries equipped with Fiscal Responsibility laws with high/low debt. Ratio of the cumulative increase in the net present value of GDP and the cumulative increase in the net present value of government consumption. Triggered by a shock to government consumption. 


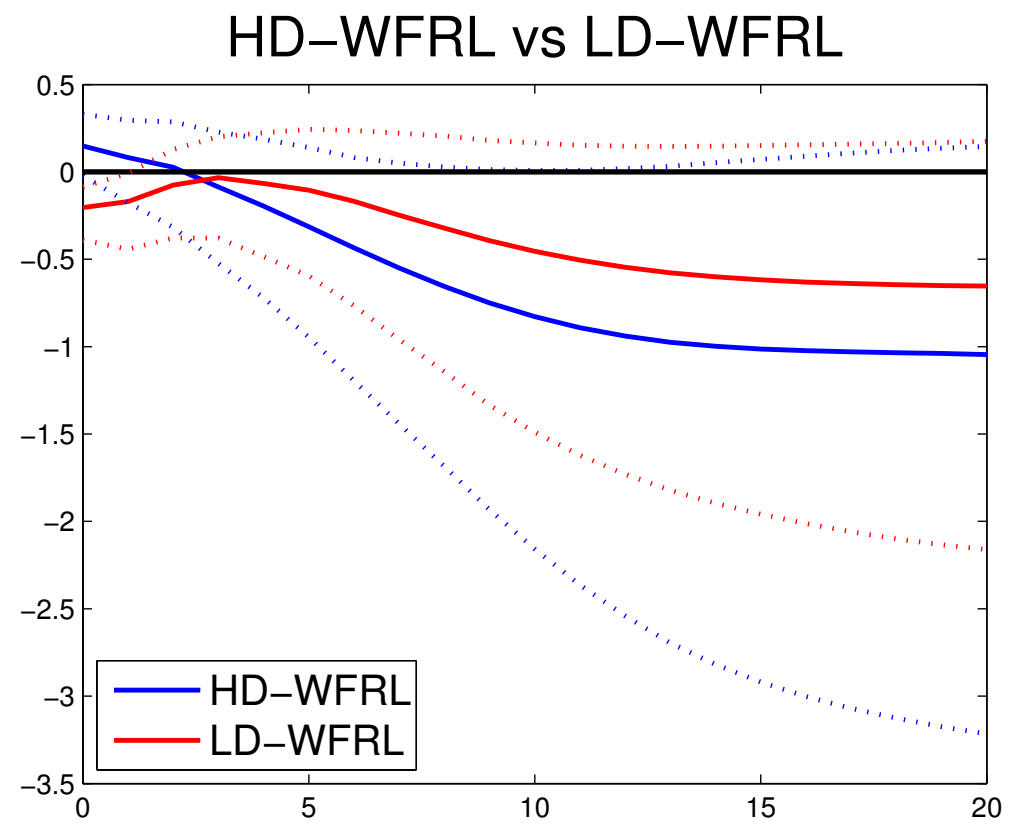

Figure 5.14: IPVAR Cumulative multiplier: Countries without Fiscal Responsibility laws with high/low debt. Ratio of the cumulative increase in the net present value of GDP and the cumulative increase in the net present value of government consumption. Triggered by a shock to government consumption. 


\section{6 \\ Conclusion}

This paper tries to check if the usage of different measures of fiscal fragility corroborate previously obtained results in relation to the magnitude of fiscal multipliers. These new measures of fiscal fragility are obtained uniting the theory behind government's intertemporal budget constraint and the literature on politico-institutional determinants on deficits. We highlight again that these factors can be interpreted as the difficulty to react to an expansionary fiscal shock by increasing fiscal balances on the future.

We obtain evidence that when countries have politico-institutional characteristics that are expected to weaken their primary results' path, they will have lower multipliers than when they do not have those referred characteristics. These results are more pronounced when we are dealing with countries that have/don't have fiscal responsibility laws, although the other state-variables also corroborate these effects.

When we condition our analysis both on the debt size and in our fiscal balances' path proxies, results also indicate that countries in a less solvent situation have lower multipliers. However, when countries have features that indicate they will obtain good primary results on the future, it is not clear if the level of indebtedness continues to affect fiscal multipliers negatively. Yet these are weak results, it could be interest to analyse this question more deeply in future works. 


\section{References}

[1] HALL, R. E. By how much does gdp rise if the government buys more output? National Bureau of Economic Research, v. w15496, 2009.

[2] BARRO, R. J. Government spending in a simple model of endogeneous growth. Journal of political economy, v. 98, n. 5, Part 2, p. S103-S125, 1990.

[3] ASCHAUER, D. A. Is public expenditure productive? Journal of monetary economics, v. 23, n. 2, p. 177-200, 1989.

[4] AUERBACH, A.; J GORODNICHENKO, Y. Measuring the output responses to fiscal policy. American Economic Journal: Economic Policy, v. 4, n. 2, p. 1-27, 2012.

[5] ILZETZKI, E.; MENDOZA, E. G.; VEGH, C. A. How big (small?) are fiscal multipliers? Journal of monetary economics, v. 60, n. 2, p. 239-254, 2013.

[6] BUDINA, N.; KINDA, T.; SCHAECHTER, A.; WEBER, A. Fiscal rules in response to the crisis: Toward the"next-generation"rules: A new dataset. IMF Working Paper 12/187, 2012.

[7] BECK, T.; CLARKE, G.; GROFF, A.; KEEFER, P.; WALSH, P. New tools in comparative political economy: The database of political institutions. the world bank economic review, v. 15, n. 1, p. 165-176, 2001.

[8] HUIDROM, R.; KOSE, A.; LIM, J. J.; OHNSORGE, F. Do fiscal multipliers depend on fiscal positions? World Bank Policy Research Working Paper, v. 7724, p. 1-39, 2016.

[9] ALESINA, A.; PEROTTI, R. The political economy of budget deficits. IMF Staff Papers, v. 42, n. 1, 1995.

[10] ESLAVA, M. The political economy of fiscal deficits: a survey. Journal of Economic Surveys, v. 25, n. 4, p. 645-673, 2011.

[11] BARRO, R. On the determination of the public debt. Journal of political Economy, v. 87, n. 5, Part 1, p. 940-971, 1979. 
[12] LAVIGNE, R. The political and institutional determinants of fiscal adjustment: Entering and exiting fiscal distress. European Journal of Political Economy, v. 27, n. 1, p. $17-35,2011$.

[13] ALESINA, A.; HAUSMANN, R.; HOMMES, R.; STEIN, E. Budget institutions and fiscal performance in latin america. Journal of development Economics, v. 59, n. 2, p. 253-273, 1999.

[14] VON HAGEN, J. A note on the empirical effectiveness of formal fiscal restraints. Journal of Public Economics, v. 44, n. 2, p. 199-210, 1991.

[15] MILESI-FERRETTI, G. M. Good, bad or ugly? on the effects of fiscal rules with creative accounting. Journal of Public Economics, v. 88, n. 1, p. 377394, 2004.

[16] ALT, J.; LASSEN, D. Fiscal transparency, political parties, and debt in OECD countries. European Economic Review, v. 50, n. 6, p. 1403-1439, 2006.

[17] TABElLINI, G.; ALESINA, A. Voting on the budget deficit. American Economic Review, v. 80, n. 1, p. 37-49, 1990.

[18] GRILLI, V.; MASCIANDARO, D.; TABELLINI, G. Political and monetary institutions and public financial policies in the industrial countries. Economic policy, v. 6, n. 13, p. 341-392, 1991.

[19] BLANCHARD, O.; PEROTTI, R. An empirical characterization of the dynamic effects of changes in government spending and taxes on output. the Quarterly Journal of economics, v. 117, n. 4, p. 1329-1368, 2002.

[20] RAMEY, V. A.; SHAPIRO, M. D. Costly capital reallocation and the effects of government spending. Carnegie-Rochester Conference Series on Public Policy, v. 48, p. 145-194, 1998.

[21] TOWBIN, P.; WEBER, S. Limits of floating exchange rates: The role of foreign currency debt and import structure. Journal of Development Economics, v. 101, p. 179-194, 2013.

[22] LIENERT, I. Should advanced countries adopt a fiscal responsibility law? IMF Working Paper, v. 10/254, 2010.

[23] PEROTTI, R. Fiscal policy in good times and bad. The Quarterly Journal of Economics, v. 114, n. 4, p. 1399-1436, 1999. 
A

\section{Data Appendix}

\section{A.1 \\ Political Polarization Index}

To construct our political polarization index, we interact two variables present in 8:

- POLARIZ

\section{- ALLHOUSE}

Authors attribute a number to the ideology of all political parties in congress: 1 to left wing, 2 to center parties and 3 to right wing. Then, they compute the maximal distance between the ideology of chief executive's party and the three largest parties in government coalition and the largest party from the opposition.

When we have this maximal ideological distance between parties equal to 1 or $2^{1}$, and chief executive's party does not control all houses in congress, we are in a politically polarized environment. On the other hand, if maximal ideological distance between parties is equal to 0 and chief executive's party control all houses in congress, we are in a non polarized environment.

\footnotetext{
${ }^{1}$ We have also tried choosing only maximal distance equal to 2 , and results are robust
} 


\section{B \\ Robustness Checks}

We start showing the interaction between debt as a fiscal fragility indicator with our other politico-institutional proxies (we have only shown this analysis with fiscal responsibility laws, because the same phenomena occurs with all four state-variables.

After that, We also report here our results using the IPVAR methodology reducing our sample to High income countries only and to emerging countries only. Since there are less observations of emerging countries, confidence intervals are extremely big (that is not a problem when we reduce our sample to high-income countries). However, we also show it here in order to clarify that the phenomena of fiscal fragility affects fiscal multipliers negatively.

\section{B.1 \\ Debt and State Variables}

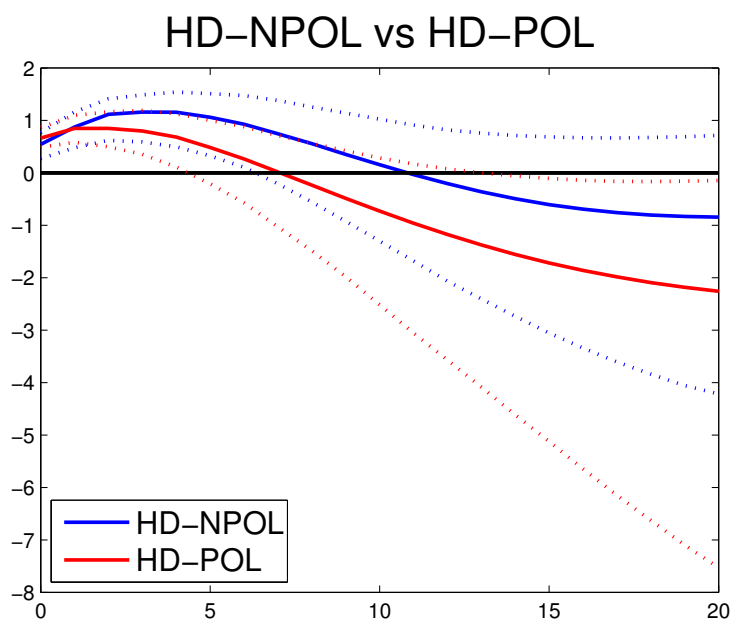

Figure B.1: IPVAR Cumulative multiplier: High Debt Countries with and without political polarization. 


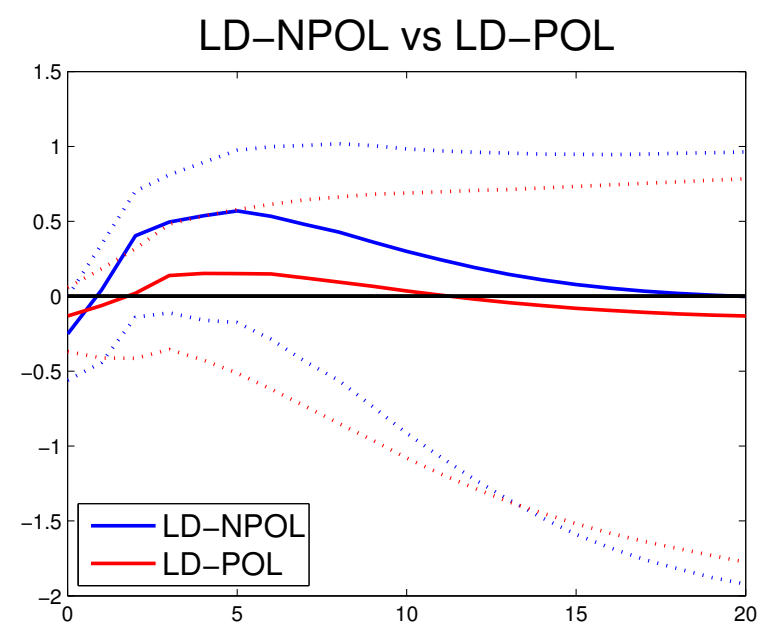

Figure B.2: IPVAR Cumulative multiplier: Low Debt Countries with and without political polarization.

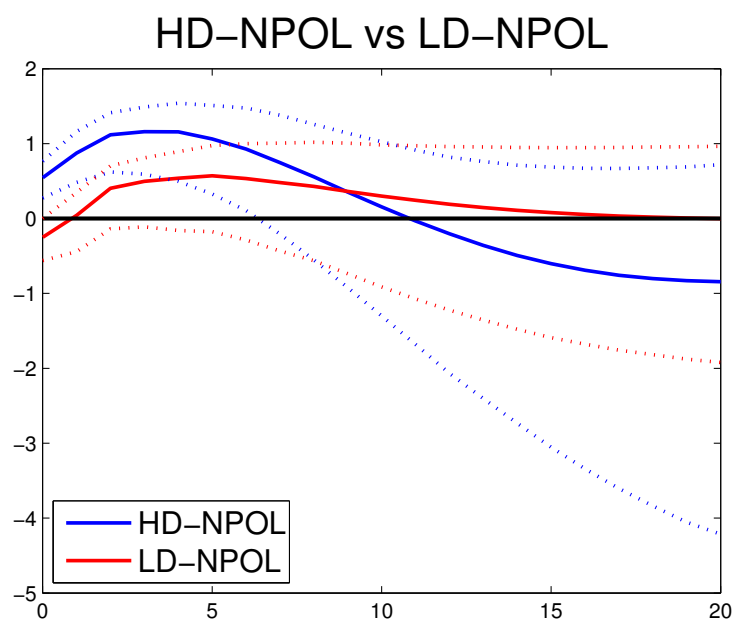

Figure B.3: IPVAR Cumulative multiplier: Countries without Political Polarization with high/low debt. 


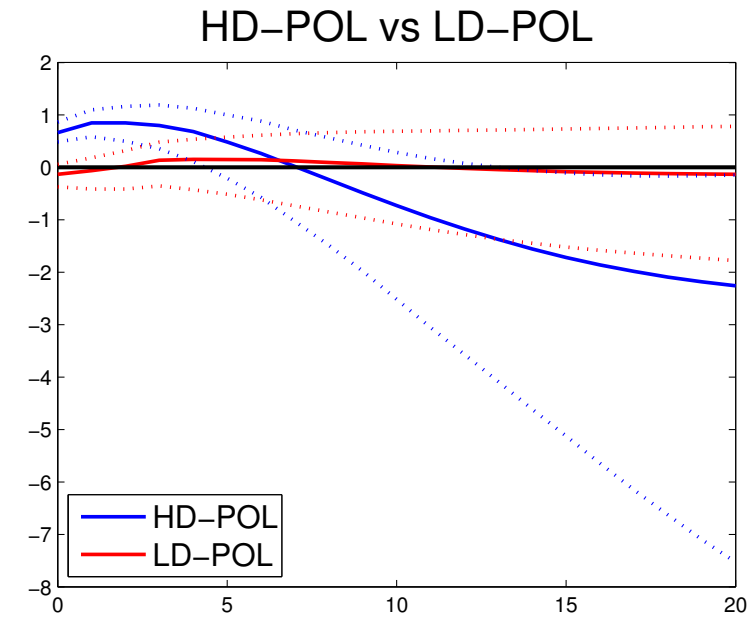

Figure B.4: IPVAR Cumulative multiplier: Countries with Political Polarization with high/low debt.

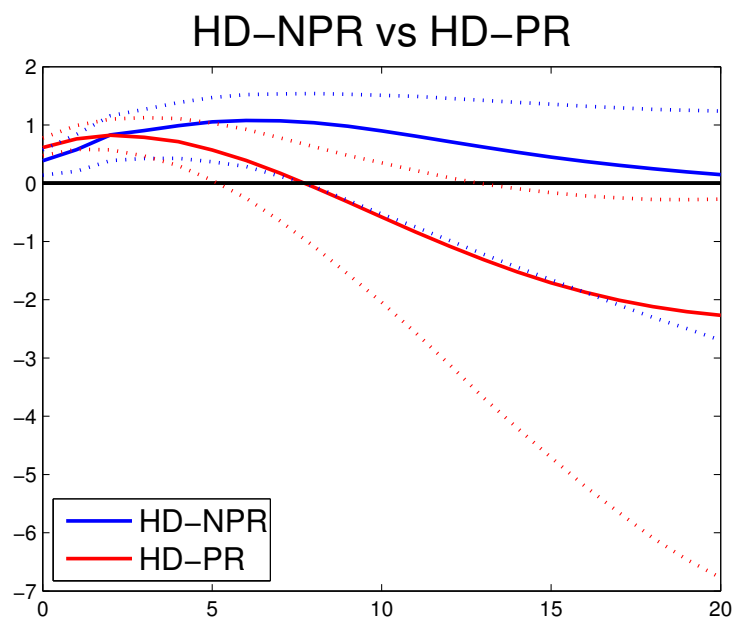

Figure B.5: High Debt Countries with and without proportional electoral system. 


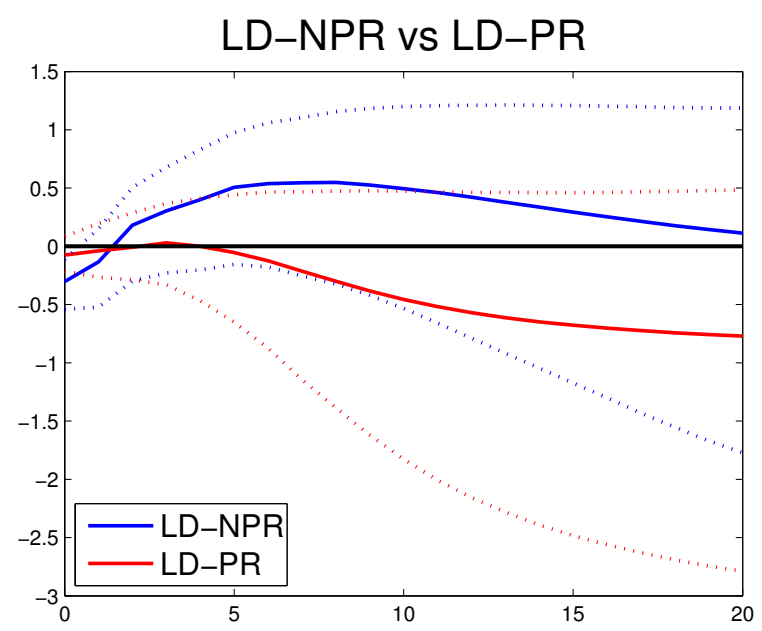

Figure B.6: IPVAR Cumulative multiplier: Low Debt Countries with and without proportional electoral system..

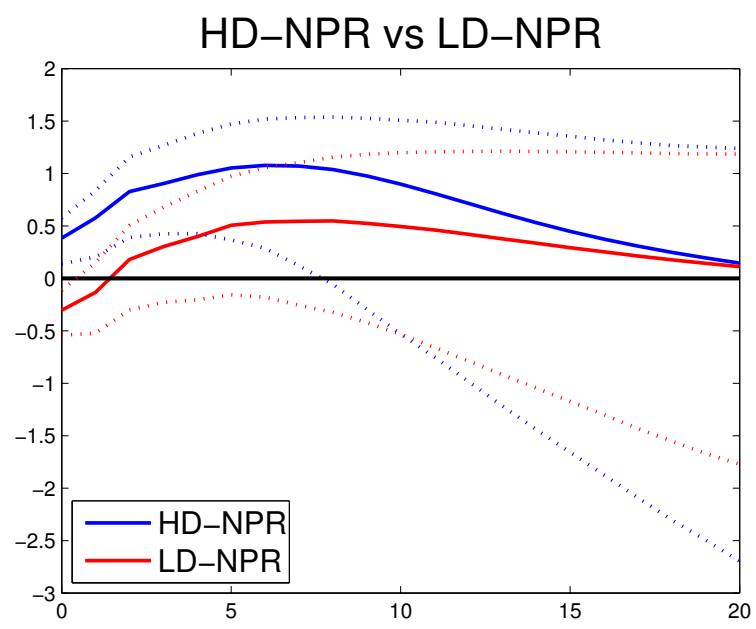

Figure B.7: IPVAR Cumulative multiplier: Countries without proportional electoral system with high/low debt. 


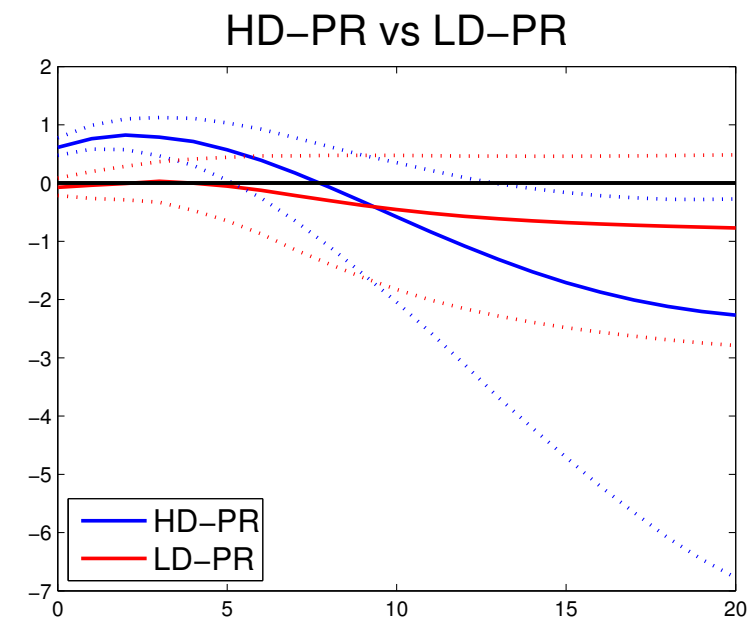

Figure B.8: IPVAR Cumulative multiplier: Countries with proportional electoral system with high/low debt.

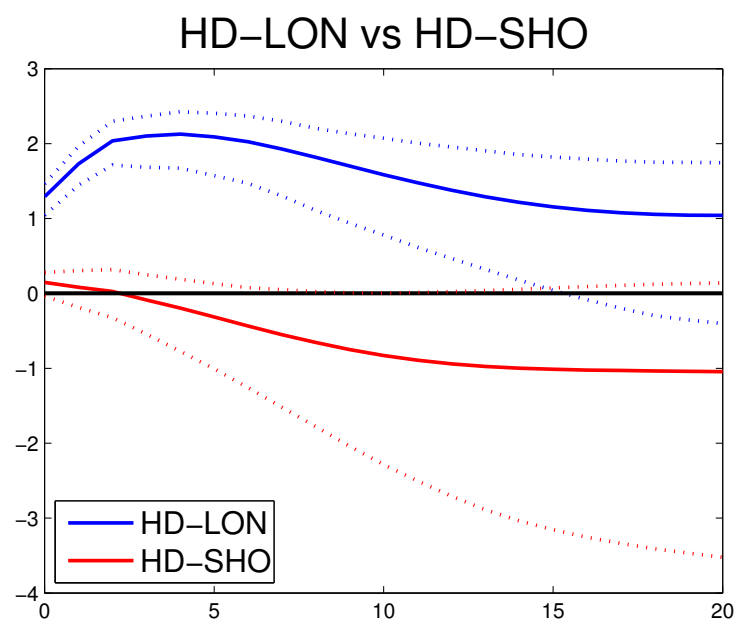

Figure B.9: IPVAR Cumulative multiplier: High Debt Countries with short/long tenures. 


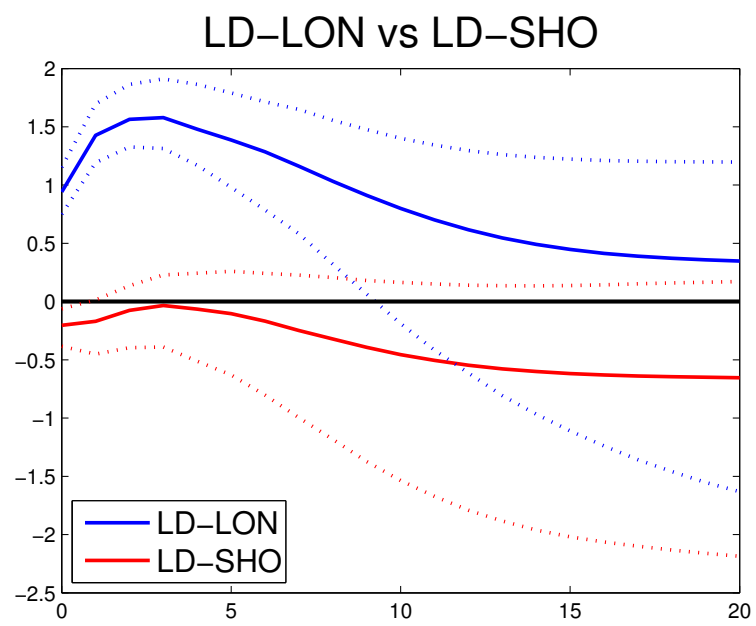

Figure B.10: IPVAR Cumulative multiplier: Low Debt Countries short/long tenures.

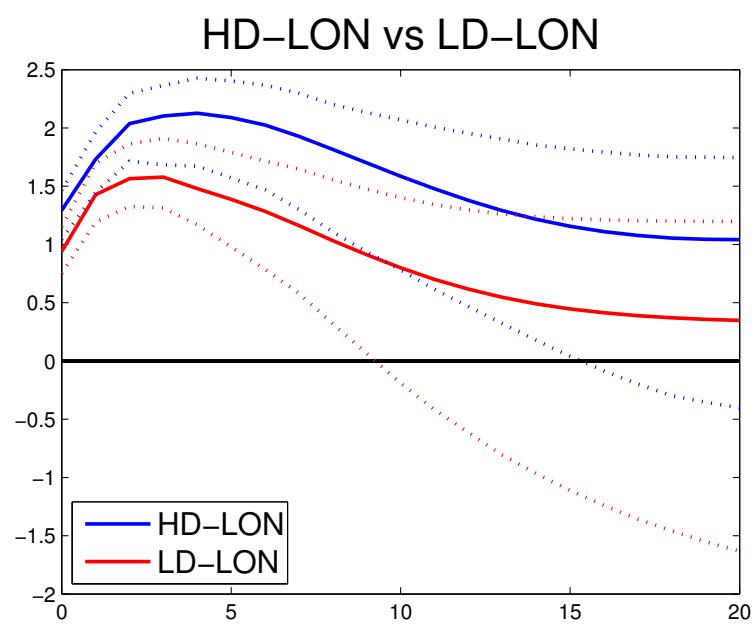

Figure B.11: IPVAR Cumulative multiplier: Countries with Long Tenures with high/low debt. 


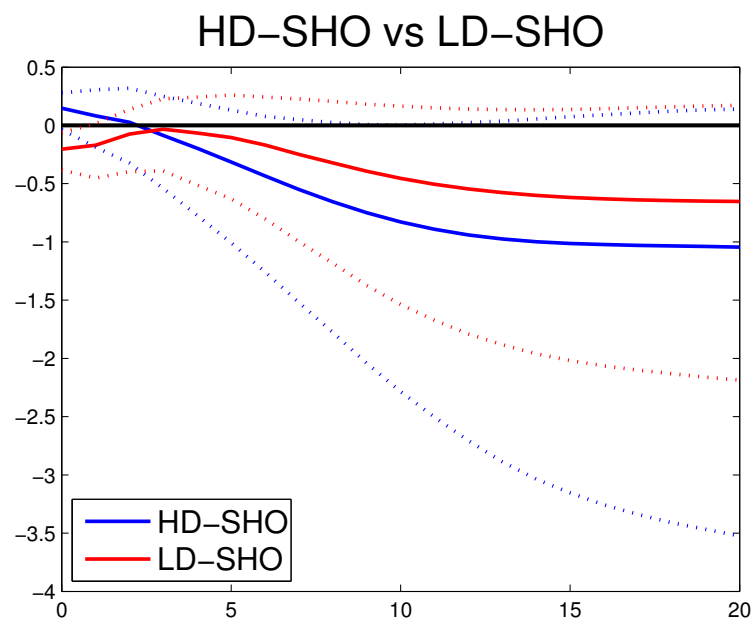

Figure B.12: IPVAR Cumulative multiplier: Countries with Short Tenures with high/low debt. 
B.2

High income countries

High Income FRL vs WFRL

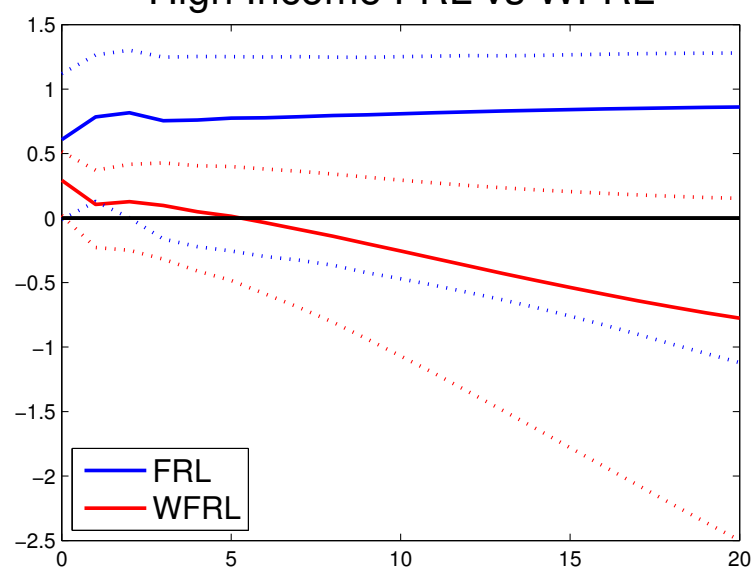

Figure B.13: IPVAR Cumulative multiplier: High Income Countries with/without Fiscal Responsibility Law. 
High Income NPOL vs POL

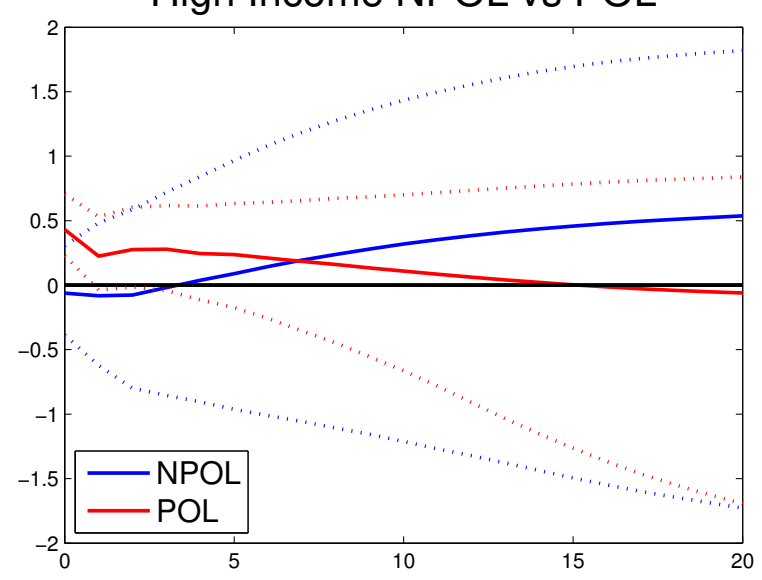

Figure B.14: IPVAR Cumulative multiplier: High Income Countries with/without Political Polarization.

High Income NPR vs PR

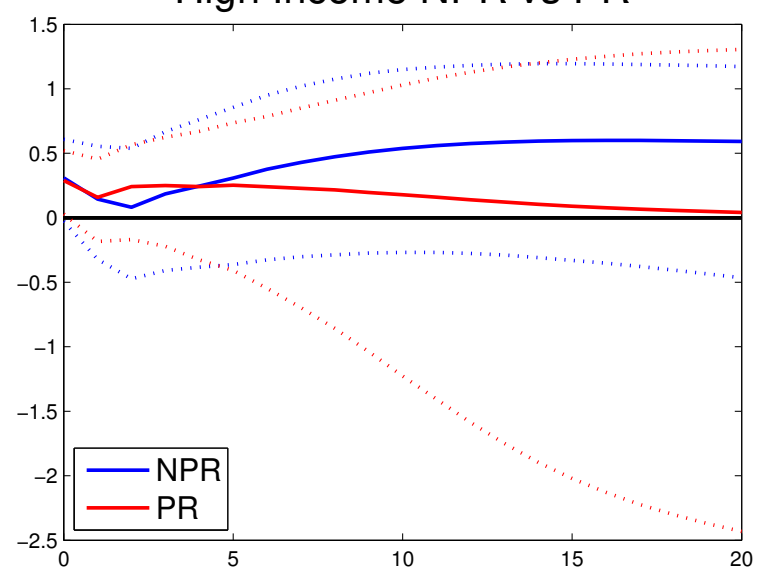

Figure B.15: IPVAR Cumulative multiplier: High Income Countries with/without Proportional Electoral System.

High Income LON vs SHO

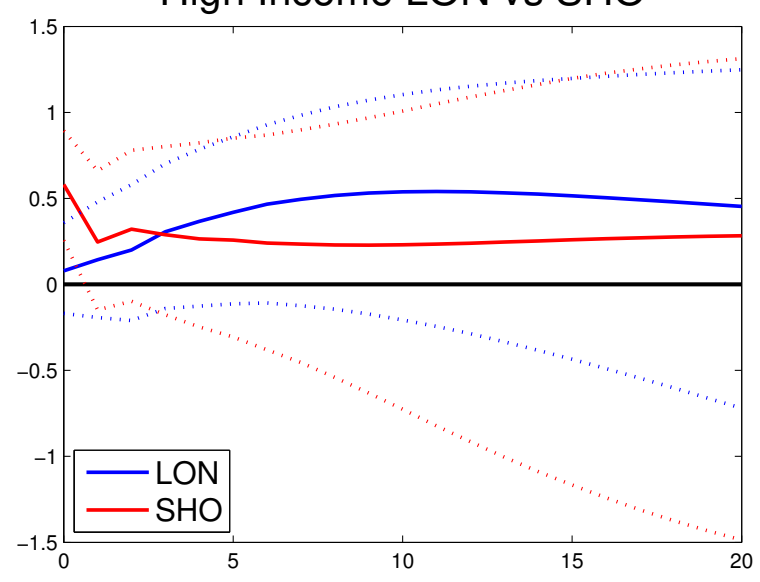

Figure B.16: IPVAR Cumulative multiplier: High Income Countries with long/short tenure. 


\section{B.3}

\section{Emerging countries}

Developing WFRL vs FRL

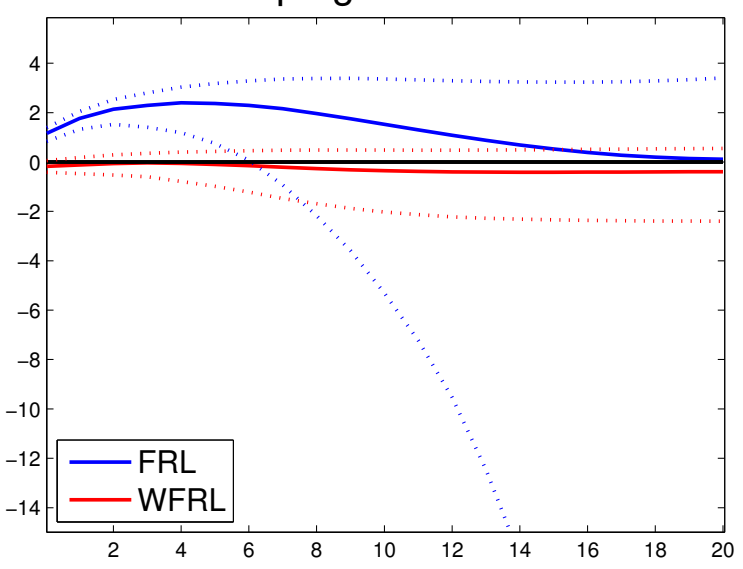

Figure B.17: IPVAR Cumulative multiplier: Emerging Countries with/without Fiscal Responsibility Law. 


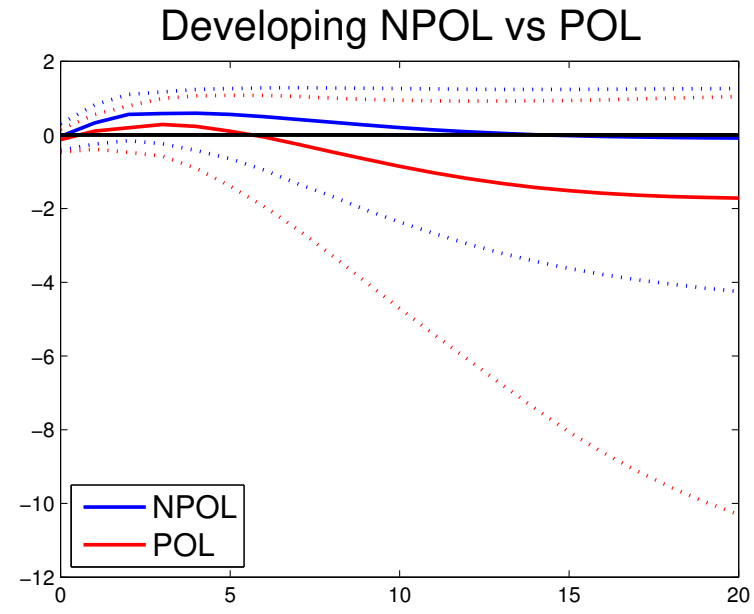

Figure B.18: IPVAR Cumulative multiplier: Emerging Countries with/without Political Polarization.

Developing NPR vs PR

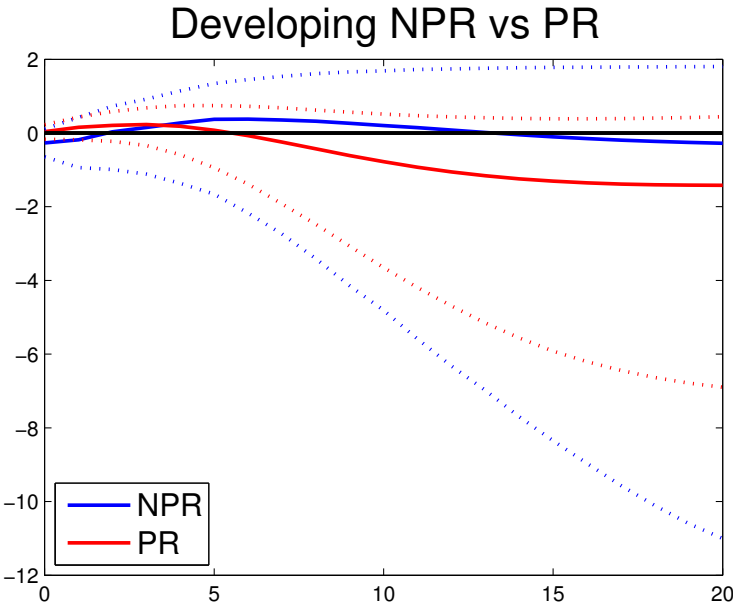

Figure B.19: IPVAR Cumulative multiplier: Emerging Countries with/without Proportional Electoral System.

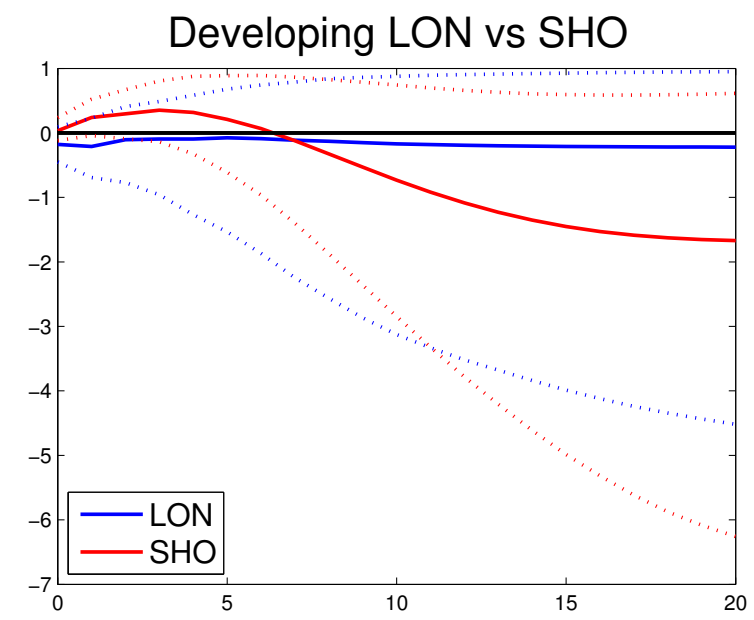

Figure B.20: IPVAR Cumulative multiplier: Emerging Countries with long/short tenure 